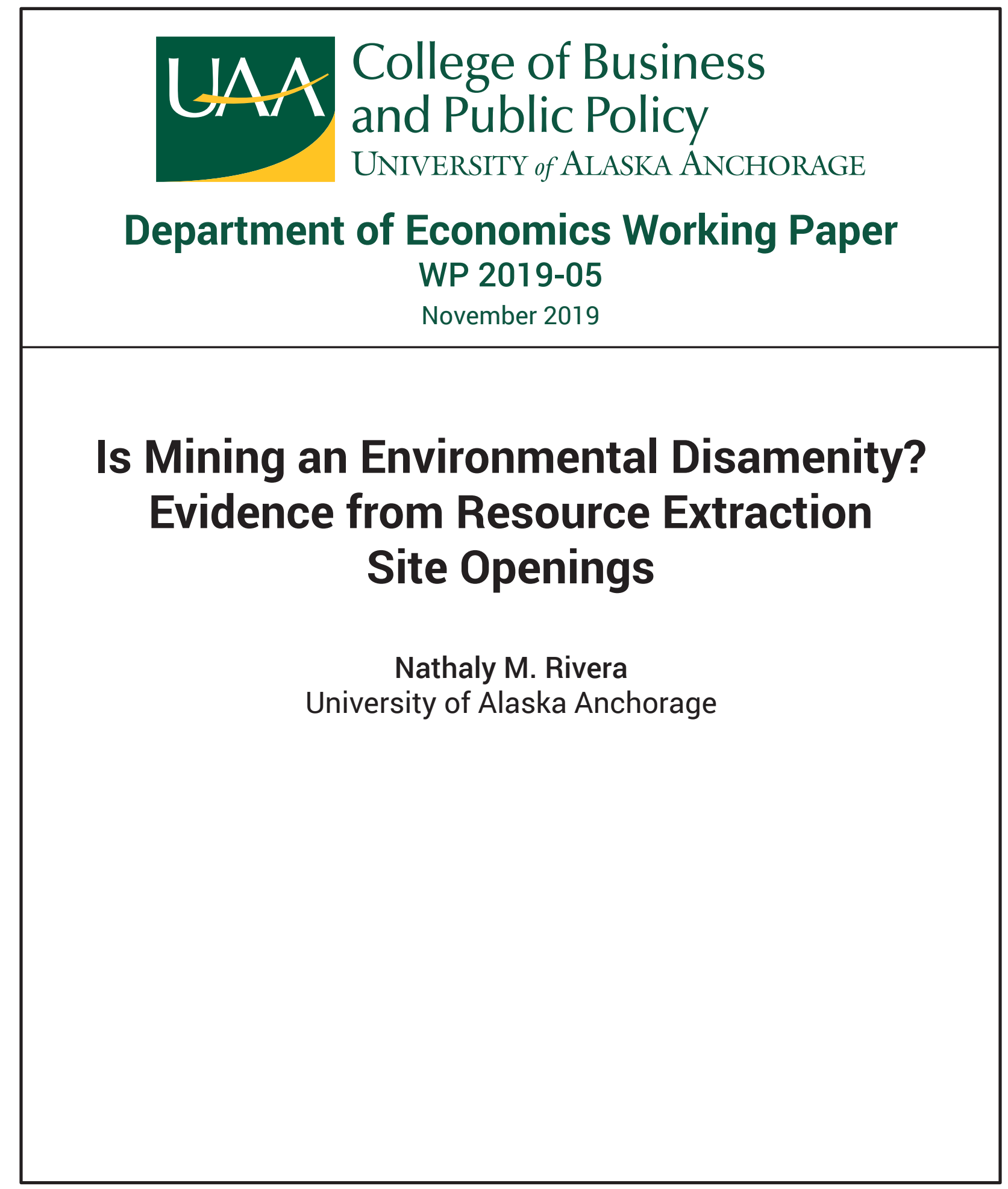

UAA DEPARTMENT OF ECONOMICS

3211 Providence Drive

Rasmuson Hall 302

Anchorage, AK 99508

http://econpapers.uaa.alaska.edu/ 


\title{
Is Mining an Environmental Disamenity? Evidence from Resource Extraction Site Openings
}

\author{
Nathaly M. Rivera*
}

November 13, 2019

\begin{abstract}
Extractive industries are often challenged by nearby communities due to their environmental and social impacts. If proximity to resource extraction sites represents a disamenity to households, the opening of new mines should lead to a decrease in housing prices. Using evidence from more than 6,000 new extraction sites in Chile, this study addresses whether the heavy environmental and social impacts of digging activities outweigh their local economic benefits to the housing market in emerging economies. Findings from a spatial difference-in-difference nearest-neighbor matching estimator reveal that households near mining activity get compensated with lower rental prices, mostly in places with high perceptions of exposure to environmental pollution. Further analysis suggests that this compensation is lower among new residents of mining towns, which constitutes evidence of a taste-based sorting across space. Results in this study bring to light the need of incorporating welfare effects of potential social and environmental disruptions in future studies addressing the economic impact of new mining operations.
\end{abstract}

Keywords: Extractive Industries, Mining, Environmental Valuation, Environmental Disamenities, Hedonic Models, Nearest-Neighbor Matching Estimator.

JEL Classification: Q53, Q51, Q32, Q34

*Department of Economics and Public Policy, University of Alaska Anchorage, Anchorage, AK 99508. nmrivera@alaska.edu 


\section{Introduction}

More than 3.5 million people around the world live in places rich in oil, gas and minerals (World Bank, 2018b). Whether these resources are a threat to human health and environmental quality rather than an economic opportunity remains yet an open research question. Common extraction activities, such as blasting, hauling, and drilling, release high levels of both particulate matter and gaseous pollutants such as sulfur dioxide $\left(\mathrm{SO}_{2}\right)$, nitrogen oxides $\left(\mathrm{NO}_{X}\right)$, and carbon monoxide $(\mathrm{CO})$, all contributing to local air pollution. Water quality is also threatened. The high concentration of chemicals and materials in land surrounding extraction sites, in combination with large amounts of water from mining processes, increase the likelihood of mine discharges into streams and rivers. Tailing management, noise, and visual pollution are also part of the environmental impacts of these activities, which in combination with soil degradation can threaten both agricultural production and human settlement. $^{1}$

Many resource-rich economies suffer from corruption and a general disruption of social activities as well. Resource rents can induce rent-seeking, clientelism, and patronage among local politicians (Gylfason, 2001; Robinson et al., 2006; Kolstad and Søreide, 2009), leading to poor economic performances of resource-rich economies (Mehlum et al., 2006). These places are also described as areas with low welfare indicators (Bulte et al., 2005), and high social distortions such as changes in the local population (Petrova and Marinova, 2013), induced displacement and resettlement (Chakroborty and Narayan, 2014), pressures on local infrastructure (Mason et al., 2015; Petrova and Marinova, 2013), low levels of trust (Petrova and Marinova, 2013), increased criminal activity (James and Smith, 2017; Komarek, 2018), truck accidents (Graham et al., 2015; Muehlenbachs et al., 2017), and increased prostitution and sexually transmitted diseases (Pegg, 2006; Komarek and Cseh, 2017).

When proximity to extractive industries represents a disamenity to households, new ex-

\footnotetext{
${ }^{1}$ See more in Milu et al. (2002); Kitula (2006); Bebbington et al. (2008); Kemp et al. (2010).
} 
traction activity should generally lead to a decrease in the price of neighboring houses. ${ }^{2}$ This paper addresses this idea studying whether the heavy environmental and social impacts of extractive activities outweigh their local economic benefits on the housing market. Despite the wide variety of studies exploring housing market capitalization of proximity to environmental disamenities, ${ }^{3}$ the empirical understanding of the property value impacts of proximity to mining sites is still limited. Evidence from previous studies on housing and drilling activities offers some guidance, although with mixed evidence (Boxall et al., 2005; Weber, 2012; Gopalakrishnan and Klaiber, 2013; Muehlenbachs et al., 2013a, 2015; Boslett et al., 2016; Delgado et al., 2016; Jacobsen, 2019). Moreover, digging ore out of the ground, as opposed to pumping oil or gas to the surface, features pronounced impacts on the ecosystem and important environmental hazards such as dust and noise emissions, particularly with more invasive methods such as open-cast operations or surface mining (Williams, 2011). This paper contributes to this previous literature by approximating the causal impact on rental prices of proximity to the concentration of digging activities. To the best of the author's knowledge, this is the first study on the property value effects of proximity to mining that uses household-level information prioritizing causality.

This paper uses the case of Chile, one of the fastest-growing countries in Latin America (World Bank, 2018a). Chile has a substantial mining industry that has strongly contributed to its economic development, setting the guidelines on mining regulation in many other emerging economies. While extractive industries account for several local economic benefits in these countries (Aragon and Rud, 2013; Loayza and Rigolini, 2016), recent social and environmental movements have increased social opposition to new mines (Bebbington et al.,

\footnotetext{
${ }^{2}$ This is particularly true for countries with laxer environmental regulations. Broner et al. (2012) suggest that countries holding a comparative advantage in polluting industries might have laxer environmental regulations due their lobbying exerted to prevent the enactment of stringent standards. This is in line with the 2016 The Economist article titled "From Conflict to Co-operation", on the mistrust existing among locals regarding the stringency of environmental impact assessments that are submitted by local mining projects. Source: From Conflict to Co-operation, The Economist, Online, accessed June 12, 2017.

${ }^{3}$ See for instance Kohlhase (1991); Mendelsohn et al. (1992); Greenstone and Gallagher (2008); GamperRabindran and Timmins (2013) on proximity to hazardous waste sites or Superfund sites; Kiel and McClain (1995a,b) on waste incinerators; Currie et al. (2015) on industrial plants; Gamble and Downing (1982) on nuclear plants; and Davis (2011) on power plants.
} 
2008; Urkidi, 2010), raising concerns around the real local benefits of these projects. The case of Chile provides an opportunity to delve deeper into the net effects of extractive industries in settings where the social returns from these activities are constantly challenged. In turn, this work adds to the scarce literature on proximity to environmental disamenities in places characterized by less stringent environmental regulations, and broadly, to the growing field of environmental valuation in developing countries (Greenstone and Jack, 2015).

The focus of this paper is on the universe of new resource extraction sites opened in Chile during 2011 and 2016. ${ }^{4}$ Using data from the National Service of Geology and Mining, this study identifies three types of mine openings that constitute three treatments: all-size mine openings; small, medium and large-scale (conventional) mine openings; and artisanal mine openings that groups small-scale mines operating under rudimentary conditions. ${ }^{5}$ Cities hosting the exclusive opening of one of these sites are part of a treated group of cities. Cities with no mining records are part of a control group of cities, and locations with mine records but zero openings are part of a placebo group of cities. ${ }^{6}$ This information is merged with repeated cross-sectional data on more than 24,000 households and their rental housing prices. Rental prices are superior to housing prices in hedonic housing valuation as they reflect the market's current valuations of housing attributes instead of combining these valuations with the market's expectations about future conditions (Harrison Jr and Rubinfeld, 1978). At the same time, they show a greater sensitivity to local changes as the rental market exhibits a faster turnover than the housing market, which tends to be more affected by frictions such as

\footnotetext{
${ }^{4}$ This paper avoids a cross-sectional comparison of rental prices between cities with and without mining due to Chile's historical mining tradition, which goes back to the 19th century. This situation challenges identification as it is unfeasible to control for city-level attributes and housing characteristics before the establishment of the first extraction sites. Instead, the opening of new deposits facilitates a clearer definition of the event study and the study period, which ultimately allows to proper control for potential differences across cities before these openings.

${ }^{5}$ It is important to distinguish artisanal mining from conventional mining due to the potential small economic impacts of the former relative to large-scale operations, and their less-sustainable production and management practices that could impose higher net detrimental effects on households. See Section 4 for more details on the different impacts.

${ }^{6}$ Chile is administratively divided into 346 communes -or cities- grouped into 15 regions. Comparing with the U.S. administrative division, cities are equivalent to counties, while regions are the equivalent to states.
} 
credit market imperfections and long-term contracts (Rosen and Smith, 1983). ${ }^{7}$ Nonetheless, under the holistic understanding that properties for rent are part of a comparable housing market, these findings can approximate the effects of mining sites on the housing market as well. ${ }^{8}$

Two quasi-experimental techniques are used for identification. First, a spatial differencein-difference (DID) hedonic price equation compares households in treated cities to households in control cities before and after the openings. ${ }^{9}$ A DID estimator improves hedonic price estimations by reducing any potential bias in marginal willingness-to-pay (MWTP) calculations that come from time-constant omitted variables or uncontrolled time-varying implicit prices (Kuminoff et al., 2010). A second approach combines the previous spatial DID with a nearest-neighbor matching procedure that finds a match for treated houses from the set of control houses, comparing them before and after the sitings. This spatial DID nearest-neighbor matching estimator (DIDNNM) uses the distance between a set of covariates unaffected by the treatment to construct a group of comparable houses in control cities, improving the balance of observables across groups and reducing any potential bias from observables that confound the original DID specification.

The results strongly suggest that mine openings represent an environmental disamenity to households. Overall, the concentration of new mines outweighs their local economic benefits on the housing rental market, leading to a 10-17 percent reduction in monthly rental prices of nearby houses. ${ }^{10}$ This represents a marginal willingness to pay of $30-62$ USD to avoid

\footnotetext{
${ }^{7}$ I am very thankful to an anonymous referee for pointing this out.

${ }^{8}$ For all the purposes, the study period covers years with low copper prices. Copper prices increased until 2011, declining afterward until their lowest drop in 2016. Source: Chilean Copper Commission, Online, accessed July 15, 2018. The effect of this price bust on rental prices is carefully taken into consideration in the empirical strategy.

${ }^{9}$ In an ideal setting, effects of proximity to the disamenity would be measured by restricting the sample to houses that are located within a specific radius of distance. Unfortunately, the available data restrict this type of analysis. Findings in this study, however, bring to light the net impacts of cities' concentration of extraction sites on the value of housing units for rent.

${ }^{10}$ These results are in line with similar estimates on proximity to disamenities in other developing countries. For instance, Arimah (1996) estimates that households in Nigeria are willing to pay around 9 percent of their housing rent in order to live $1 \mathrm{~km}$ away from a major landfill boundary, while Deng et al. (2014) estimate a 12-14 percent increase in the price of properties within $5 \mathrm{~km}$ of two polluting power plants in China after the relocation of these facilities.
} 
proximity to the concentration of mines, equivalent to a $7-14 \%$ of the country's minimum wage. Further analysis show that rental price impacts are exacerbated by both the type and the number of new mines, and by the kind of mining technique.

Given mining's high pollution potential, this paper also tests for heterogeneous effects of mine openings at different levels of environmental degradation. With the aim of creating a tool that integrates environmental valuation with pollution concentrations, environmental degradation is measured using households' perceptions of air and water pollution, linked later to objective measures of environmental quality. ${ }^{11}$ The results strongly suggest that the negative rental price impact of new extraction activity is aggravated in places with high environmental pollution. Namely, the opening of conventional sites constitutes a disamenity but mostly in areas with high airborne contamination, while the disamenity effect of new artisanal sites is mostly tied to high levels of water contamination.

Previous research has shown evidence of a taste-based sorting of individuals across space (Chay and Greenstone, 2005) to the extent that households that downplay social and environmental disamenities are likely to sort into less pleasant places, which might add bias to MWTP measures. This paper tests the existence of sorting by studying heterogeneous effects among new and old residents of treated and control cities. Evidence of significant differences in treatment effects among these groups represents a simple test of a preference-based sorting of households. Findings reveal that the disamenity effect is less critical for new residents of mining towns, suggesting that households new to these cities are likely minimizing the disamenity effect.

The remainder of this work proceeds as follows. Section 2 outlines the hedonic price model, while section 3 details the resource extraction in Chile. Section 4 describes the data. Section 5 outlines the empirical strategy, while Section 6 presents the results and the

\footnotetext{
${ }^{11}$ Evidence shows that subjective measures outperform objective indicators on environmental amenities (Berezansky et al., 2010; Chasco and Gallo, 2013) by reducing the upward bias arising from a potential mismatch between these metrics (Michael et al., 2000). Another reason advocating for the use of subjective measures is the difficulty of interpreting objective measures of environmental quality, which prompts individuals to base their location decisions on their own insights of local pollution (Chasco and Le Gallo, 2015).
} 
robustness checks, and discusses potential identification threats. Section 7 concludes.

\section{Analytical Framework}

\subsection{A Brief on the Hedonic Price Model}

This study uses the hedonic price model to elicit willingness-to-pay measures for a nonmarginal degradation in local environmental quality due to the opening of new mines. ${ }^{12}$ Scholars applying hedonic price modeling to associate housing prices and quantities of environmental quality date back to Ridker (1967) and Ridker and Henning (1967), who first conceived the value of a house as a function of its structural, neighborhood, and environmental characteristics (Freeman, 1979). ${ }^{13}$ This section briefly describes the hedonic price method and its implications when evaluating a local deterioration in an environmental amenity. The model predicts that rental prices decrease in response to a deterioration in environmental quality.

The hedonic price theory considers that an item $h$ can be valued by a vector $z$ of characteristics $\left(z_{1}, z_{2}, \ldots, z_{j}\right)$. In the case of a house, these characteristics include structural and neighborhood characteristics and local environmental quality. The price of house $h$, therefore, can be considered as the sum of each of its homogeneous attributes in a price function described as follows:

$$
P_{h}(z)=P\left(z_{1}, z_{2}, \ldots, z_{j}\right)
$$

This function $P_{h}(z)$ is referred to as the hedonic price function and indicates the amount that an individual must pay for a bundle with characteristics $z$. The partial derivative of $P_{h}(\cdot)$ with respect to $z_{j}, \partial P_{h}(\cdot) / \partial z_{j}$, gives the marginal implicit price of characteristic $z_{j}$. Utility-maximizing individuals derive, at the same time, utility from a housing item $h$. In the

\footnotetext{
${ }^{12} \mathrm{New}$ mining activity is expected to generate social impacts as well (see the previous section). For the sake of simplicity, however, this section only considers a change in local environmental quality.

${ }^{13}$ For a more comprehensive review of hedonic price applications, see Mendelsohn and Olmstead (2009) and Freeman III et al. (2014).
} 
housing market equilibrium arising from the interactions of buyers and sellers, individuals' marginal willingness to pay (WTP) for characteristic $z_{j}$ equals the marginal implicit price of that characteristic.

Rosen (1974) distinguishes the price hedonic function $P_{h}(z)$ from the bid function $\theta_{i}=\theta\left(M, z_{j}, z_{-j}, u^{*}\right)$, which represents what an individual $i$ is willing to pay for different values of characteristic $z_{j}$, holding income $M$, other characteristics $z_{-j}$, and utility constant at a level $u^{*}$. Heterogeneous individuals' preferences and income lead to different bid functions, and so to different chosen quantities of characteristic $z_{j}$. The relationship between the hedonic price function $P_{h}(z)$, and the bid functions $\theta_{1}$ and $\theta_{2}$ for individuals 1 and 2, respectively, for characteristic $z_{j}$ is depicted in Figure 1.

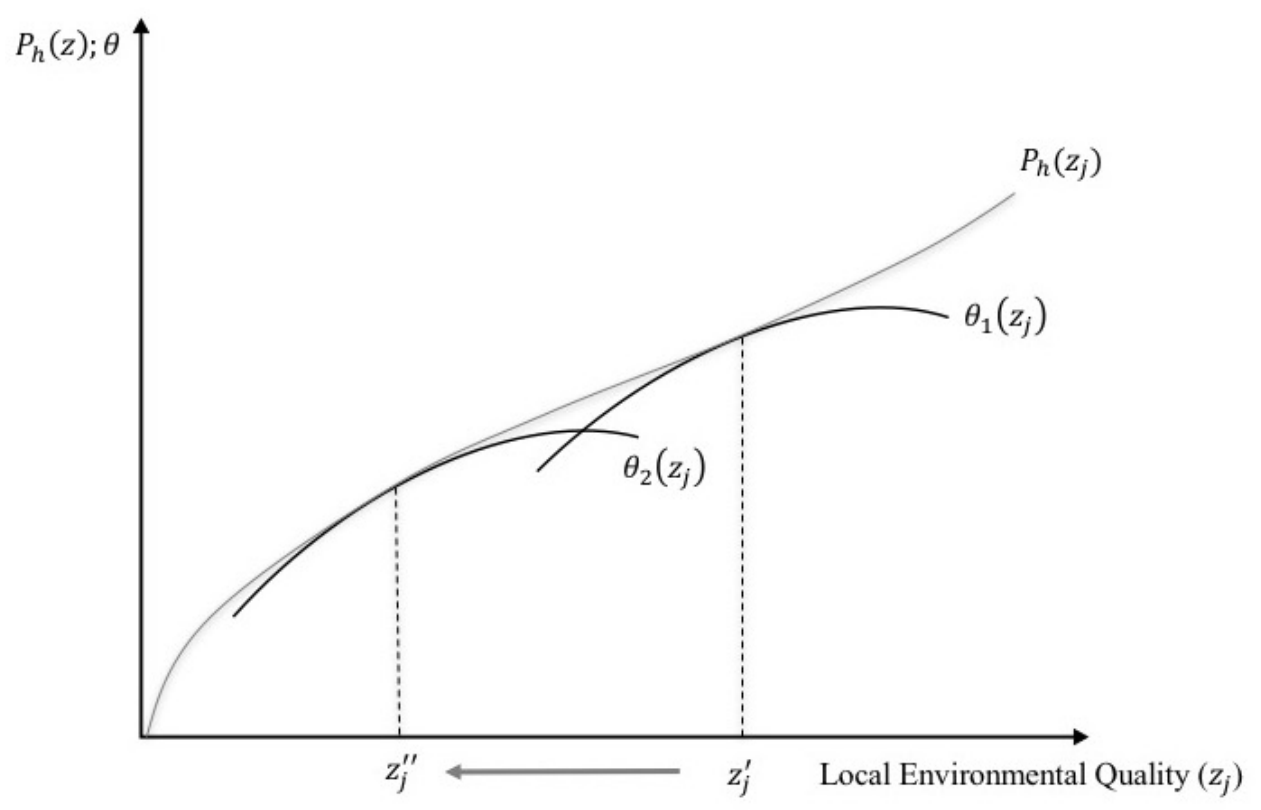

Figure 1: Bid Curves and the Hedonic Price Function in a Hedonic Market for Local Environmental Quality

Suppose $z_{j}$ is a measure of local environmental quality. Figure 1 shows that both bid functions exhibit diminishing marginal willingness to pay for $z_{j}$, and that given the hedonic price function, individuals 1 and 2 choose levels of environmental quality where their marginal WTP for $z_{j}$ equals the marginal implicit price determined by the hedonic price function at 
$z_{j}^{\prime}$ and $z_{j}^{\prime \prime}$, respectively. Given the market equilibrium, individuals' utilities would be lower at sites with higher or lower levels of environmental quality.

\subsection{A Localized Change in Environmental Quality}

This study aims to capture the impact of proximity to resource extraction site openings on rental prices. The mechanisms behind these impacts are both the local economic effects of new mining activity capitalized into housing prices, and a non-marginal decrease in local environmental (and social) quality due to the high-pollution potential of these new sites. To establish the welfare effects of this non-marginal change, it is assumed that the change in environmental quality is a localized change (Palmquist, 1992), and therefore, the hedonic price function does not shift in response to this variation. This is a valid assumption as the number of cities (and households) in this study experiencing the treatment represents only a small portion of the entire rental market in Chile (see Table 1). Hence, any environmental quality degradation in these cities will not be sufficient to force a significant relocation of individuals that could lead to a new hedonic price equation. ${ }^{14}$

Consider now that the opening of new resource extraction sites deteriorates environmental quality in the neighborhood from $z_{j}^{\prime}$ to $z_{j}^{\prime \prime}$. From Figure 1, this non-marginal change is expected to decrease the price of house $h$. For individual 1 originally consuming $z_{j}^{\prime}$, the new price for environmental quality falls below her/his WTP for the environmental quality amenity. This individual can decide to relocate to a place with better environmental quality and restore the equilibrium, in which case the net welfare effect of the non-marginal change in $z_{j}$ comes from the reduction in wealth to the homeowner individual. If the individual stays, she/he would be worse off due to a decrease in environmental quality even though she/he would be paying less for occupying the house. The implied change in total welfare from the environmental quality degradation, therefore, can be obtained by multiplying the

\footnotetext{
${ }^{14} \mathrm{An}$ alternative approach to assessing a non-marginal change in a locational amenity is to estimate the bid functions as suggested by Rosen (1974). As shown later on the paper, however, a taste-based sorting prevents this estimation as preferences vary across individuals.
} 
observed equilibrium price differential due to the resource extraction site openings by the number of residential housing rental units.

\section{Resource Extraction in Chile}

Chile is one of the world's leading mining countries, many times referred to as the "mining capital of Latin America". The country holds important mineral reserves of copper, gold, iodine, lithium, molybdenum, natural nitrates, rhenium, silver, and zinc (USGS, 2014), with the entire industry accounting for $28 \%$ of the copper production, $23 \%$ of the molybdenum production, and $6 \%$ of the silver production worldwide. Among other factors, this vast amount of ore reserves explains the relevance of the industry for the national economy. Nowadays, this sector contributes to $13 \%$ of Chile's GDP, $15 \%$ of national taxes, $50 \%$ of national exports, and 12\% of total employment (Consejo Minero, 2017).

The mining industry in Chile features large-, medium-, and small-scale operations, and unlike many other places in Latin America, there is no evidence of illegal mining in the country. ${ }^{15}$ These operations can have state or private ownership. Primarily, mineral resources in the ground are owned by all Chilean citizens, with legal ownership vested to the private sector through government-granted rights to either explore or extract the resource. The 1983 National Mining Code (NMC) outlines the mechanisms for the concession of these property rights, establishing a single request to the local civil court as the main step in this process. Currently, a total of $31,183,231 \mathrm{Ha}$ is held by these concessions, equivalent to $41 \%$ of the national territory (SERNAGEOMIN, 2013). About half of these concessions are granted for extraction, where the main state-owned company, CODELCO, accounts for less than $6 \%$ of participation (COCHILCO, 2016). CODELCO's production indeed represents almost 30\% of Chile's total copper production, followed closely by ESCONDIDA, the largest foreign-owned mine in Chile, controlled mostly by BHP, a multinational mining company with presence in

\footnotetext{
${ }^{15}$ See "Organized Crime and Illegal Gold Mining in Latin America", Global Americans, Online, accessed July $6,2018$.
} 
several other countries such as Australia, Brazil, Canada, Mexico, and the United States.

While the strong contribution of mining to Chile's development is undeniable, this sector is accountable for high social and environmental impacts. Mining towns have reported the highest rates of AIDS in the country, generally perceived a consequence of increased prostitution and alcoholism rates in these areas, together with elevated rates of suicides and divorces commonly linked to the long shift systems, which force mining workers to be absent from home several days each week (Aroca, 2001). Low availability of local amenities has also been pointed as a distinctive feature of mining towns in Chile (Paredes and Rivera, 2017), generally associated to a reduced amount of backward and forward linkages of mining companies in these areas (Aroca, 2001; Arias et al., 2013; Rivera and Aroca, 2014).

Regarding environmental degradation, copper smelters are the highest emitters of $\mathrm{SO}_{2}$ in the country, and of particulate matter (PM) in mining cities (Ministry of Environment, 2011). Studies on soil composition also show high concentrations of copper, arsenic and antimony in many valleys of the country (De Gregori et al., 2003), and local analyses on mining and social disputes relate most of these conflicts to tailing management, glacier destruction issues, and water scarcity (Transparency International, 2018). This last issue has become a topic of high concern in Chile given the increasing use of water by the mining industry. After its use, this resource is sometimes released back into natural courses, increasing the risks of water and soil contamination (Sánchez and Enríquez, 1996). This risk is intensified in areas where miners opt for abandoning their mills and other precarious installations once the extraction is over, a practice that is generally attributed to artisanal miners (Sánchez and Enríquez, 1996). Finally, the existence of tailing dams, acid drainage, abandoned mine sites, and biodiversity and habitat, adds to the broad set of challenges as well (Newbold, 2006).

Despite these environmental risks being common to large, medium, and small-scale mining, current environmental standards are primarily oriented towards large-scale operations, with small-scale mining remaining mostly unregulated (Castro and Sánchez, 2003). Environmental law in Chile restricts $\mathrm{SO}_{2}$ and arsenic emissions that, due to the specific operations 
of this segment, apply mostly to large-scale mining. Additionally, most of these companies have attained accreditations concerned with environmental management systems to manage their environmental responsibilities and liabilities (Newbold, 2006). In any case, the pronounced social and environmental impacts of mining projects are assessed early on by the assessment system of environmental impacts, the institution in charge of evaluating new mining projects and certifying their compliance with standing environmental regulations. In extraordinary cases of dispute with social or environmental movements, however, the final decision regarding their compliance is taken by a committee of ministers, a step that may come at the cost of eliminating impartiality in the assessment process (Transparency International, 2018). There is not an equivalent assessment process, however, to evaluate the potential social impacts of these projects.

\section{Data}

\subsection{Resource Extraction Sites}

Data on extraction site openings come from the inventories of mineral sites prepared by the National Service of Geology and Mining (Servicio Nacional de Geología y Minería SERNAGEOMIN) for 2011 and 2016. This paper studies the openings of two main types of extraction sites as defined by SERNAGEOMIN: active mines and artisanal mines. ${ }^{16}$ An active mine is a small-, medium- or large-scale (hereafter called "conventional") extraction site that is under formal and continuous operation over time. ${ }^{17}$ Artisanal mines are instead a segment of small-scale mining that operate sporadically under informal and rudi-

\footnotetext{
${ }^{16} \mathrm{~A}$ distinction based on ownership (i.e. state vs. private) is not feasible as the ownership variable is omitted from the inventory. However, the number of state-owned mining companies in Chile is reduced to CODELCO and ENAMI only. One of CODELCO's divisions, the "Ministro Hales" division, started operations in 2013. Nevertheless, this division is located in the city of Calama, which is part of the cities excluded from the analysis (see Figure A1 in the Appendix). This implies that most of the openings studied here (if not all) correspond to private initiatives.

${ }^{17}$ According to the National Service of Geology and Mining (SERNAGEOMIN), a small-scale mine has less than 80 hired workers; a medium-scale mine has between 80 and 400 workers; and a large-scale mine has more than 400 workers.
} 
mentary conditions depending on the ore price (Díaz Tobar, 2015), minimizing any local economic impact relative to conventional operations. Many of these mines also tend to lack of monitoring systems, which impede the proper tracking of their environmental impact and preclude their proper regulation. Furthermore, artisanal mines' lack of financial capacity to invest in abatement technologies (Sánchez and Enríquez, 1996) hampers the application of environmental best practices, which puts them at a disadvantage in terms of corporate environmental responsibility when compared to conventional mines. Since 2011, more than 3,500 new conventional sites and around 3,000 new artisanal sites were opened in the country (see Table A1 in Appendix). ${ }^{18}$ During this period, however, many old sites closed operations as well. A total of 4,041 sites shut down, with most of these closings coming from artisanal sites, which corroborates the vulnerability of this segment.

To study the impact of mine openings on rental prices, the former site distinction is used to define three treatments at the city-level. The first treatment is the general opening of either conventional mines, artisanal mines, or both, and it is labeled "all-mine openings"; the second treatment is defined as "only conventional site openings"; while the third treatment constitutes "only artisanal site openings". Cities are classified into one of these treatment groups depending on the type of openings taking place over time, or into a control group of cities if they have no records of mining activity during this time. ${ }^{19}$ Provided that the concentration of new extraction sites is truly affecting rental prices in hosting cities, cities with a constant number of mines should exhibit no price impacts attributable to this feature. With this rationale, cities with mining activity in 2011 but with no additional openings between 2011-2016 are part of a placebo group of cities used later in a falsification test. To easily attribute price impacts to a specific event, a total of 100 cities that simultaneously host site openings and closings are dismissed from the analysis. ${ }^{20}$ Figure A2 (Appendix)

\footnotetext{
${ }^{18}$ For a spatial location of the openings see Figure A1 in Appendix.

${ }^{19}$ At same time, this classification requires that none of these cities had experienced additional closures over the study period. In this way, the number of inactive or abandoned sites in the treatment cities (if any) is kept constant, and so their potential effect on rental prices is eliminated when taking the price difference over time.

${ }^{20}$ Ideally, there would be a treatment group with cities experiencing mine closings as well. However, all
} 
illustrates the groups construction, while Figure A3 (Appendix) depicts the spatial location of cities in each group.

\subsection{Household Information}

Data on extraction sites is combined with information on rental houses, prices and structural characteristics, using the 2011 and 2015 versions of the National Socioeconomic Characteristics Survey (CASEN). Households in this survey describe the structural characteristics of their dwellings, while those declaring themselves as tenants report their monthly rent payment. Renting households in this survey add up to approximately 24,000 households over these two periods. Assuming no major differences in mine openings between 2015 and 2016, no announcement effects, and no future expectations on these openings, rental prices for 2015 will capture most of the effect of proximity to the concentration of mine sitings on the rental market.

Household information is merged with cities' attributes that might simultaneously affect the equilibrium rental price. This work considers data on local public finances and other citylevel characteristics that come from the National System of Municipal Information (SINIM). Variables such as the poverty rate and population density are used as controls for characteristics of the local economy and agglomeration economies, respectively. Other variables such as the number of public parks and squares, and per capita expenditures on waste disposal and pick-up are all considered to approximate a city's quality of life. Additionally, information on crime rates per 1,000 inhabitants from the Crime Prevention Sub-Secretary (SPD) is also considered. The final dataset contains around 14,000 households over 2 years and 264 cities, classified into one of either the treatment groups, the control group, or into a placebo

the site closures identified in the data took place in cities that simultaneously host new openings, making it hard to isolate this event. Previous evidence on the closures of toxic plants, however, shows that housing prices remain unaffected after the shutdown of these facilities due to lasting visual effects or concerns on local contamination, which in turn implies that toxic facilities continue to negatively affect housing prices even after they cease operations (Currie et al., 2015), particularly if some of these sites are left abandoned (Newbold, 2006). 
group. ${ }^{21}$ The final number of cities and households by group is depicted in Table 1, while Table A2 (Appendix) displays the descriptive statistics of the main variables in the sample.

\begin{tabular}{|c|c|c|c|c|c|c|}
\hline Period & Group & Unit & $\begin{array}{l}\text { All-Mine } \\
\text { Openings }\end{array}$ & $\begin{array}{l}\text { Only Conventional } \\
\text { Mine Openings }\end{array}$ & $\begin{array}{l}\text { Only Artisanal } \\
\text { Mine Openings }\end{array}$ & Placebo \\
\hline \multirow{4}{*}{2011} & \multirow{2}{*}{ Treated } & Cities & 51 & 13 & 12 & 11 \\
\hline & & Households & 1,669 & 208 & 667 & 655 \\
\hline & \multirow{2}{*}{ Control } & Cities & 173 & 173 & 173 & 173 \\
\hline & & Households & 4,570 & 4,570 & 4,570 & 4,570 \\
\hline \multirow{4}{*}{2015} & \multirow{2}{*}{ Treated } & Cities & 51 & 13 & 12 & 11 \\
\hline & & Households & 2,078 & 186 & 902 & 353 \\
\hline & \multirow{2}{*}{ Control } & Cities & 173 & 173 & 173 & 173 \\
\hline & & Households & 5,454 & 5,454 & 5,454 & 5,454 \\
\hline
\end{tabular}

Notes: Chile is administratively divided into 346 communes -or cities- grouped into 15 regions. All-mine openings consider cities with only opening of conventional mines, only opening of artisanal mines, and the simultaneous opening of both sites (for more on the construction of groups, see Figure A2). This treatment, therefore, includes more cities than the last two groups together.

Table 1: Number of Cities and Households by Group

Table 2 displays the mean characteristics of the main covariates by groups for the 2011 pre-treatment period. Panel A shows dwellings' characteristics, while panel B displays cities' attributes. Columns (1)-(4) display means by group, while columns (5)-(7) display p-values from mean comparisons among the treatments and the control group. Mean comparisons in columns (5), (6) and (7) reject the null hypothesis of equal means across groups for most of the covariates, revealing their imbalance across groups. Covariate imbalance among treated and control units might add bias to the difference-in-difference estimation, as these units may not necessarily have the same distribution over observed variables. To deal with this concern, units in treated and control groups are adjusted through a matching procedure explained in detail in the next section.

\footnotetext{
${ }^{21}$ The other 10,000 households are those homes located in cities that, due to the simultaneous opening and closing of mines, are dismissed from the analysis.
} 


\begin{tabular}{|c|c|c|c|c|c|c|c|}
\hline \multirow{3}{*}{ Variables } & \multicolumn{4}{|c|}{ Means } & \multicolumn{3}{|c|}{ p-values } \\
\hline & $\begin{array}{l}\text { All-Mine } \\
\text { Openings }\end{array}$ & $\begin{array}{l}\text { Only Conventional } \\
\text { Mine Openings }\end{array}$ & $\begin{array}{l}\text { Only Artisanal } \\
\text { Mine Openings }\end{array}$ & $\begin{array}{l}\text { Control } \\
\text { Group }\end{array}$ & (1) vs. (4) & (2) vs. (4) & (3) vs. (4) \\
\hline & (1) & $(2)$ & (3) & (4) & (5) & (6) & (7) \\
\hline \multicolumn{8}{|l|}{ Panel A. House-Level Characteristics } \\
\hline \# of Bedrooms & 2.280 & 2.303 & 2.119 & 2.338 & 0.03 & 0.59 & 0.00 \\
\hline \# of Bathrooms & 1.172 & 1.038 & 1.266 & 1.112 & 0.00 & 0.02 & 0.00 \\
\hline \multicolumn{8}{|c|}{ Dwelling Type (Base $=$ substandard $)$} \\
\hline Proportion Row Units & 0.382 & 0.394 & 0.302 & 0.408 & 0.06 & 0.68 & 0.00 \\
\hline Proportion Single-Family Units & 0.308 & 0.587 & 0.245 & 0.445 & 0.00 & 0.00 & 0.00 \\
\hline Proportion Apts. (elev.) & 0.132 & - & 0.294 & 0.040 & 0.00 & 0.00 & 0.00 \\
\hline Proportion Apts. (no elev.) & 0.158 & 0.019 & 0.116 & 0.090 & 0.00 & 0.00 & 0.04 \\
\hline \multicolumn{8}{|c|}{ Walls Material (Base $=$ substandard $)$} \\
\hline Proportion Reinforced Concrete & 0.220 & 0.053 & 0.335 & 0.111 & 0.00 & 0.01 & 0.00 \\
\hline Proportion Masonry & 0.473 & 0.514 & 0.344 & 0.389 & 0.00 & 0.00 & 0.03 \\
\hline Proportion Drywall & 0.244 & 0.356 & 0.228 & 0.479 & 0.00 & 0.00 & 0.00 \\
\hline \multicolumn{8}{|l|}{ Walls Condition (Base $=$ bad $)$} \\
\hline Proportion Regular & 0.673 & 0.558 & 0.699 & 0.609 & 0.00 & 0.14 & 0.00 \\
\hline Proportion Good & 0.248 & 0.341 & 0.227 & 0.295 & 0.00 & 0.15 & 0.00 \\
\hline \multicolumn{8}{|c|}{ Floor Material $($ Base $=$ substandard $)$} \\
\hline Proportion Wood & 0.364 & 0.308 & 0.546 & 0.451 & 0.00 & 0.00 & 0.00 \\
\hline Proportion Tile & 0.412 & 0.466 & 0.245 & 0.359 & 0.00 & 0.00 & 0.00 \\
\hline Proportion Carpet & 0.084 & 0.019 & 0.120 & 0.077 & 0.39 & 0.00 & 0.00 \\
\hline Proportion Cement & 0.054 & 0.019 & 0.040 & 0.044 & 0.08 & 0.09 & 0.62 \\
\hline \multicolumn{8}{|l|}{ Floor Condition $($ Base $=$ bad $)$} \\
\hline Proportion Regular & 0.653 & 0.505 & 0.680 & 0.609 & 0.00 & 0.00 & 0.00 \\
\hline Proportion Good & 0.260 & 0.356 & 0.251 & 0.296 & 0.01 & 0.06 & 0.02 \\
\hline \multicolumn{8}{|c|}{ Roof Material (Base $=$ substandard) } \\
\hline Proportion Roof Tiles & 0.091 & 0.029 & 0.114 & 0.106 & 0.08 & 0.00 & 0.52 \\
\hline Proportion Concrete & 0.208 & 0.010 & 0.303 & 0.074 & 0.00 & 0.00 & 0.00 \\
\hline Proportion Zincstrips & 0.697 & 0.962 & 0.580 & 0.819 & 0.00 & 0.00 & 0.00 \\
\hline Proportion Clinkstone & 0.004 & - & 0.003 & 0.000 & 0.00 & 0.76 & 0.02 \\
\hline \multicolumn{8}{|l|}{ Roof Condition (Base = bad) } \\
\hline Proportion Regular & 0.686 & 0.567 & 0.728 & 0.645 & 0.00 & 0.02 & 0.00 \\
\hline Proportion Good & 0.226 & 0.322 & 0.207 & 0.259 & 0.01 & 0.04 & 0.00 \\
\hline \multicolumn{8}{|l|}{ Dimension $\left(\right.$ Base $\left.=<30 \mathrm{~m}^{2}\right)$} \\
\hline Proportion $30-40 \mathrm{~m}^{2}$ & 0.247 & 0.236 & 0.230 & 0.260 & 0.29 & 0.43 & 0.10 \\
\hline Proportion $41-60 \mathrm{~m}^{2}$ & 0.351 & 0.413 & 0.314 & 0.353 & 0.90 & 0.07 & 0.05 \\
\hline Proportion $61-100 \mathrm{~m}^{2}$ & 0.217 & 0.149 & 0.262 & 0.197 & 0.09 & 0.09 & 0.00 \\
\hline Proportion $101-150 \mathrm{~m}^{2}$ & 0.058 & 0.063 & 0.064 & 0.050 & 0.21 & 0.42 & 0.13 \\
\hline Proportion $+150 \mathrm{~m}^{2}$ & 0.016 & 0.014 & 0.018 & 0.015 & 0.93 & 0.91 & 0.58 \\
\hline \multicolumn{8}{|l|}{ Panel B. City-Level Attributes } \\
\hline Density $\left(\mathrm{km}^{2}\right)$ & 372.8 & 110.1 & 978.9 & $1,348.3$ & 0.03 & 0.18 & 0.69 \\
\hline Crime (per 1,000/inab.) & $3,064.3$ & $2,246.4$ & $4,029.5$ & $2,768.9$ & 0.34 & 0.28 & 0.04 \\
\hline Poverty $(\%)$ & 15.25 & 17.09 & 14.45 & 19.39 & 0.00 & 0.34 & 0.05 \\
\hline Waste Disposal (\%) & 0.195 & 0.161 & 0.207 & 0.250 & 0.04 & 0.06 & 0.39 \\
\hline \# of Parks (p.c.) & 0.120 & 0.096 & 0.299 & 0.120 & 1.00 & 0.86 & 0.33 \\
\hline \# of Public Squares (p.c.) & 4.007 & 11.590 & 1.023 & 0.681 & 0.04 & 0.00 & 0.22 \\
\hline
\end{tabular}

Notes: The crime variable considers criminal offenses of strong social connotation. p.c. = per capita.

Table 2: Balance Table of Mean Pre-Treatment (2011) Characteristics

\subsection{Air and Water Pollution Perceptions}

Households' perceptions of air and water pollution come from the 2015 version of CASEN.

Two indexes of pollution at the city-level are constructed from these perceptions, which 
are related later to objective measures of environmental quality. The link between these indexes and objective indicators of pollution reduces any multicollinearity problem generally associated with the use of multiple pollutants or measures of environmental quality (Boyle and Kiel, 2001).

Objective indicators of air pollution come from the Emissions and Pollutant Transfers Register (RETC), containing records of annual pollutant emissions for the entire country. In particular, this study considers 2015 ton/year emissions of four criteria air pollutants widely known for causing smog and a broad range of adverse health effects (U.S. Environmental Protection Agency, 2013): fine particulate matter $\left(\mathrm{PM}_{2.5}\right)$, carbon monoxide (CO), nitrogen dioxide $\left(\mathrm{NO}_{X}\right)$, and sulfur dioxide $\left(\mathrm{SO}_{2}\right)$. Similarly, 2015 ton/year water emissions of total suspended solids (TSS) from RETC are used for water pollution. Due to reduced data availability, measures other than emissions such as population density (as a proxy for the local economy's dynamism), and the regional monthly average streamflow of main rivers (as

a proxy for the availability of recreational water reservoirs), are also considered to approximate water pollution levels. After examining the 2015 relationship between these measures and pollution perceptions, the 2011 cities' average prediction of pollution perceptions are calculated using the 2011 versions of objective indicators. Details on this imputation are provided in the next section.

\section{Empirical Strategy}

\subsection{Households' Perceptions of Air and Water Quality}

On a four-point scale that ranges from "never" to "always", households in 2015 CASEN state the frequency with which they observe air pollution in their neighborhoods and water pollution in nearby lakes, estuaries, and rivers. Drawing on the ordinal but subjective characteristic of these variables, this work assigns weights to each of these categories using ridit analysis (Bross, 1958). Ridit scoring is a non-parametric tool utilized to compare 
more than two datasets with ordered qualitative data. It uses the observed distribution of households to construct a numerical quantity ("ridit") that in this case will serve as an index of pollution perception. Let $x_{1}, x_{2}, \ldots, x_{n}$ be the ordered categories on the perception variable, and $p$ be the probability function defined with respect to the reference category as $p_{i}=\operatorname{Prob}\left(x_{i}\right)$ with $i=1, \ldots, n$. A ridit is calculated as follows:

$$
\text { Ridit }_{i}=\left\{\begin{array}{lll}
0.5 p_{i}+\sum_{k<i} p_{k} & \text { if } & i>1 \\
0.5 p_{i} & \text { if } & i=1
\end{array}\right.
$$

Intuitively, a ridit works as a modified notion of a percentile in the sense that a low ridit value for category $i$ can be interpreted as only a few households choosing a category $k$ such that $k<i$. Table A3 (Appendix) reports the ridits calculation for 2015 households' perceptions of air and water pollution, with column (5) containing the final score. These ridits are later averaged at the city level to construct two indexes of air and water pollution perceptions to regress on objective measures of environmental quality. Under a time-invariant partial relationship assumption, estimation coefficients from these regressions are used to input 2011 city-level averages. To do so, let $Y_{j}$ be a fractional random variable representing city $j$ 's average pollution perception taking realizations $y_{j}$ on the unit interval $[0,1]$. The conditional probability of $Y_{j}$ being equal to $y_{j}$ is defined as follows:

$$
P\left(Y_{j}=y_{j} \mid \mathbf{X}_{\mathbf{j}}\right)=E\left(Y_{j} \mid \mathbf{X}_{\mathbf{j}}\right)=\frac{\exp \left(\mathbf{X}_{\mathbf{j}} \gamma\right)}{1+\exp \left(\mathbf{X}_{\mathbf{j}} \gamma\right)}
$$

where $E\left(Y_{j} \mid \mathbf{X}_{\mathbf{j}}\right)$ is the conditional mean function defined as the logistic function, and $\mathbf{X}_{\mathbf{j}}$ is a vector of covariates (including a constant).

As explained in the previous section, the vector $\mathbf{X}_{\mathbf{j}}$ includes variables on $\mathrm{PM}_{2.5}, \mathrm{CO}, \mathrm{NO}_{X}$, and $\mathrm{SO}_{2}$ emissions whenever $Y_{j}$ indicates air pollution perceptions; and variables on TSS, average streamflow in rivers, and density whenever $Y_{j}$ represents water pollution perceptions. Because realizations of $Y_{j}$ take values between 0 and 1 , estimation of equation 3 applies findings in Papke and Wooldridge (1996) and uses a Bernoulli Quasi-Maximum Likelihood 
Estimator (QMLE) fractional logit regression with 2015 information. After getting the vector of estimated coefficients, $\hat{\gamma}$, predictions of 2011 cities' average pollution perceptions are calculated using 2011 versions of the covariates. Results for average marginal effects in equation 3 , and their significance, are omitted from the results section, but are displayed in the Appendix (see Table A4). Table A5 (Appendix) displays the summary statistics for these indexes, which are later transformed into a standard z-score to ease their interpretation.

\subsection{Spatial Difference-in-Difference Hedonic Price Estimation}

If the resource extraction activity represents a disamenity to households, rental prices should decrease in cities hosting new mine openings relative to prices in these cities had mine sites not been opened. Given that this control is not available for observational data, this study tackles this question using a spatial difference-in-difference (DID) approach that considers pre- and post-treatment data for a group of treated and control cities. In addition to allowing identification of average treatment effects by capturing group-level and time-level omitted variables (Angrist and Pischke, 2008), a DID estimation reduces the bias from timeinvariant omitted variables, and ensures the proper control of time-variant implicit prices (Kuminoff et al., 2010). The spatial DID hedonic price equation is defined as follows:

$$
r_{h j t}=\alpha+\delta_{1} 1[T]_{j}+\delta_{2} 1[\text { After }]+\delta_{3} 1[T]_{j} \times 1[\text { After }]+\mathbf{H}_{\mathbf{h j t}} \zeta+\phi_{j}+\epsilon_{h j t},
$$

where $r_{h j t}$ is the natural $\log$ of the rental price paid by household $h$ in city $j$ during year $t$, with $h=1, \ldots, H, j=1, \ldots, J$, and $H>J ; 1[T]_{j}$ is an indicator variable taking 1 if city $j$ belongs to a treatment group, and 0 if $j$ belongs to the control group; 1 [After] is an indicator variable taking 1 if year $t=2016$, and 0 otherwise; $\mathbf{H}_{\mathbf{h j t}}$ is a vector of covariates on housing units and city-level characteristics, including air and water pollution; and $\epsilon_{h j t}$ is an idiosyncratic effect. Equation 4 also includes dummies by region, $\phi_{j}$ (generalized later into dummies by region $\times$ year, $\phi_{j t}$ ), aimed at controlling for time-invariant unobservables 
(and time-variant unobservables at the macro level) that might simultaneously affect the outcome and the covariates of interest. This equation is estimated using an ordinary least square (OLS) estimator, with standard errors clustered at the region level.

The key parameter to estimate in equation 4 is $\delta_{3}$, which represents the causal effect of new mine openings on rental prices, or in other words, the average treatment effect on the treated (ATT) (Blundell and Dias, 2009). This ATT captures the net effect on rental prices of an increasing concentration of mines in the treatment group, and is expected to have a negative and significant sign whenever the disamenity effect of these sites exceeds the economic benefits that an increase in mining operations has on the housing rental market. ${ }^{22}$

\subsection{Spatial Difference-in-Difference Nearest-Neighbor Matching}

Covariates' mean characteristics displayed in Table 2 show a significant imbalance across groups, which might bias OLS estimations leading to inaccurate conclusions about the real impacts of mining. To improve this balance, a nearest-neighbor matching (NNM) estimator is added to the original DID design to compare rental prices across similar units. The NNM estimator enhances groups' comparability by using a vector $\mathbf{H}_{\mathbf{h}}$ of covariates unaffected by the treatment, to match comparable households in the control group to households in the treatment group. Units not selected as matchings are excluded from the analysis.

The NNM procedure works as follows. Let $T_{l}$ be the set of households in treatment group $l=\{1,2,3\} ; C$ the set of counterfactual households; and $r_{h}^{T_{l}}$ and $r_{h}^{C}$ be the observed rental prices (in logs) for treated and control households, respectively. For each household $h$ in treatment group $l$, define a neighborhood $\Omega_{m}^{\mathbf{H}}\left(h^{l}\right)$. NNM sets

$$
\Omega_{m}^{\mathbf{H}}\left(h^{l}\right)=\left\{k_{1}, k_{2}, \ldots, k_{m_{h}} \mid h \in T_{l},\left\|\mathbf{H}_{\mathbf{h}}-\mathbf{H}_{\mathbf{k}}\right\| s<\left\|\mathbf{H}_{\mathbf{h}}-\mathbf{H}_{\mathbf{i}}\right\| s, i \neq k\right\},
$$

\footnotetext{
${ }^{22}$ Identification of causal effects in a DID design comes from the counterfactual assumption that the trend in the rent prices for the control group is equivalent to the trend in the rent prices for the treatment group in absence of the treatment. Figure A4 (Appendix) fits this common trends assumption for the treatment groups, the control, and the placebo group, using the baseline sample. Pre-treatment periods correspond to 2009 and 2011. Unfortunately, missing data on pollution and other amenities at the city-level prevent the use of 2009 in the main analysis.
} 
where $\left\|\mathbf{H}_{\mathbf{h}}-\mathbf{H}_{\mathbf{k}}\right\| s=\left\{\left(\mathbf{H}_{\mathbf{h}}-\mathbf{H}_{\mathbf{k}}\right)^{\prime} \mathbf{S}^{-\mathbf{1}}\left(\mathbf{H}_{\mathbf{h}}-\mathbf{H}_{\mathbf{k}}\right)\right\}^{1 / 2} ; \mathbf{S}$ is a symmetric, positive-definite distance matrix; and $m$ is the smallest number such that the number of elements in $\Omega_{m}^{\mathbf{H}}\left(h^{l}\right)$ is (at least) the desired number of matches. Once control households are matched to treated households, the NNM estimates the ATT as follows:

$$
\hat{\tau}_{A T T_{l}}=\frac{1}{n_{l}} \sum_{h \in T_{l}}\left(r_{h}^{T_{l}}-\frac{1}{m_{h}} \sum_{k \in \Omega\left(h^{l}\right)} r_{k}^{C}\right)
$$

where $\Omega\left(h^{l}\right)=\Omega_{m}^{\mathbf{H}}\left(h^{l}\right)$, and $n_{l}$ and $m_{k}$ are the number of households in group $T_{l}$ and $C$, respectively. When more than one period is available, it is possible to apply the Differencein-Difference Nearest-Neighbor Matching (DIDNNM) estimator defined as follows:

$$
\hat{\tau}_{A T T-D I D_{l}}=\frac{1}{n_{l t}} \sum_{h \in T_{l t}}\left(r_{h}^{T_{l t}}-\frac{1}{m_{h}} \sum_{k \in \Omega\left(h^{l}\right)_{t}} r_{k}^{C_{t}}\right)-\frac{1}{n_{l t^{\prime}}} \sum_{h \in T_{l t^{\prime}}}\left(r_{h}^{T_{l t^{\prime}}}-\frac{1}{m_{h}} \sum_{k \in \Omega\left(h^{l}\right)_{t^{\prime}}} r_{k}^{C_{t^{\prime}}}\right),
$$

where $T_{l t}, T_{l t^{\prime}}, C_{t}$, and $C_{t^{\prime}}$ denote the treatment group $l$ and the control group $C$ in years $t$ and $t^{\prime}$ respectively.

This paper implements a DIDNNM procedure that matches at least one neighbor, with replacement, to each $h$ in the treatment group (i.e. $m=1$ ) (Dehejia and Wahba, 2012). Additionally, it considers that all the covariates included in the vector $\mathbf{H}$ in equation 4 (except variables on environmental pollution); it requires an exact match for all the discrete covariates; and it sets $\mathbf{S}$ to be the Mahalanobis distance matrix for continuous covariates.

Table 3 displays the mean characteristics by group after the NNM procedure for the pre-treatment period. As in Table 2, panel A shows dwellings' characteristics, while panel B exhibits cities' attributes. Columns (1)-(3) show the covariates' means for houses in cities with all-mine openings and its matched control group, and the p-value of their comparison. Similarly, columns (4)-(6) display the information for houses in cities with only conventional mine openings, while columns (7)-(9) are for houses in cities with only artisanal mine openings. Pre-treatment covariates show a balance improvement across groups relative to similar 


\begin{tabular}{|c|c|c|c|c|c|c|c|c|c|}
\hline \multirow{3}{*}{ Variables } & \multicolumn{2}{|c|}{ Means } & \multirow{2}{*}{ p-values } & \multicolumn{2}{|l|}{ Means } & \multirow[b]{2}{*}{ p-values } & \multicolumn{2}{|c|}{ Means } & \multirow[b]{2}{*}{ p-values } \\
\hline & $\begin{array}{l}\text { All-Mine } \\
\text { Openings }\end{array}$ & $\begin{array}{c}\text { Matched } \\
\text { Control }\end{array}$ & & $\begin{array}{l}\text { Only Conventional } \\
\text { Mine Openings }\end{array}$ & $\begin{array}{c}\text { Matched } \\
\text { Control }\end{array}$ & & $\begin{array}{l}\text { Only Artisanal } \\
\text { Mine Openings }\end{array}$ & $\begin{array}{c}\text { Matched } \\
\text { Control }\end{array}$ & \\
\hline & (1) & (2) & (3) & (4) & (5) & (6) & (7) & (8) & (9) \\
\hline \multicolumn{10}{|l|}{ Panel A. House-Level Characteristics } \\
\hline \# of Bedrooms & 2.430 & 2.352 & 0.02 & 2.301 & 2.371 & 0.43 & 2.464 & 2.348 & 0.12 \\
\hline \# of Bathrooms & 1.205 & 1.191 & 0.50 & 1.044 & 1.036 & 0.80 & 1.423 & 1.332 & 0.06 \\
\hline \multicolumn{10}{|l|}{ Dwelling Type (Base = substandard $)$} \\
\hline Proportion Row Units & 0.434 & 0.447 & 0.57 & 0.449 & 0.473 & 0.67 & 0.309 & 0.310 & 0.99 \\
\hline Proportion Single-Family Units & 0.339 & 0.315 & 0.24 & 0.551 & 0.527 & 0.67 & 0.361 & 0.358 & 0.94 \\
\hline Proportion Apt. (elev.) & 0.078 & 0.078 & 0.98 & - & - & - & 0.227 & 0.235 & 0.80 \\
\hline Proportion Apt. (no elev.) & 0.147 & 0.159 & 0.44 & - & - & - & 0.103 & 0.097 & 0.80 \\
\hline \multicolumn{10}{|l|}{ Walls Material (Base = substandard) } \\
\hline Proportion Reinforced Concrete & 0.161 & 0.145 & 0.16 & 0.044 & 0.036 & 0.72 & 0.254 & 0.245 & 0.80 \\
\hline Proportion Masonry & 0.567 & 0.601 & 0.11 & 0.596 & 0.617 & 0.71 & 0.436 & 0.435 & 0.98 \\
\hline \multicolumn{10}{|l|}{ Walls Condition (Base = bad) } \\
\hline Proportion Regular & 0.743 & 0.775 & 0.08 & 0.596 & 0.647 & 0.36 & 0.780 & 0.784 & 0.91 \\
\hline Proportion Good & 0.215 & 0.189 & 0.13 & 0.331 & 0.293 & 0.48 & 0.189 & 0.187 & 0.95 \\
\hline \multicolumn{10}{|l|}{ Floor Material $($ Base $=$ substandard $)$} \\
\hline Proportion Wood & 0.344 & 0.323 & 0.30 & 0.324 & 0.281 & 0.43 & 0.543 & 0.555 & 0.77 \\
\hline Proportion Tile & 0.484 & 0.522 & 0.08 & 0.529 & 0.599 & 0.23 & 0.275 & 0.271 & 0.91 \\
\hline Proportion Carpet & 0.065 & 0.080 & 0.39 & - & - & - & 0.117 & 0.113 & 0.88 \\
\hline Proportion Cement & 0.039 & 0.040 & 0.89 & - & - & - & 0.027 & 0.026 & 0.90 \\
\hline \multicolumn{10}{|l|}{ Floor Condition (Base = bad) } \\
\hline Proportion Regular & 0.743 & 0.774 & 0.10 & 0.544 & 0.599 & 0.34 & 0.780 & 0.898 & 0.83 \\
\hline Proportion Good & 0.214 & 0.190 & 0.16 & 0.353 & 0.317 & 0.52 & 0.189 & 0.184 & 0.87 \\
\hline \multicolumn{10}{|l|}{ Roof Material (Base = substandard $)$} \\
\hline Proportion Roof Tiles & 0.083 & 0.072 & 0.36 & 0.007 & 0.006 & 0.88 & 0.137 & 0.129 & 0.76 \\
\hline Proportion Concrete & 0.164 & 0.180 & 0.32 & - & - & - & 0.261 & 0.265 & 0.93 \\
\hline Proportion Zincstrips & 0.753 & 0.747 & 0.76 & 0.993 & 0.994 & 0.88 & 0.601 & 0.606 & 0.90 \\
\hline Proportion Regular & 0.760 & 0.790 & 0.10 & 0.596 & 0.653 & 0.31 & 0.794 & 0.803 & 0.77 \\
\hline Proportion Good & 0.190 & 0.167 & 0.18 & 0.324 & 0.281 & 0.43 & 0.165 & 0.158 & 0.82 \\
\hline \multicolumn{10}{|l|}{ Dimension $\left(\right.$ Base $\left.=<30 \mathrm{~m}^{2}\right)$} \\
\hline Proportion $30-40 \mathrm{~m}^{2}$ & 0.219 & 0.200 & 0.29 & 0.235 & 0.198 & 0.43 & 0.144 & 0.152 & 0.80 \\
\hline Proportion $41-60 \mathrm{~m}^{2}$ & 0.377 & 0.408 & 0.15 & 0.390 & 0.455 & 0.25 & 0.309 & 0.313 & 0.92 \\
\hline Proportion $61-100 \mathrm{~m}^{2}$ & 0.255 & 0.246 & 0.62 & 0.169 & 0.150 & 0.65 & 0.388 & 0.387 & 0.98 \\
\hline Proportion $101-150 \mathrm{~m}^{2}$ & 0.056 & 0.051 & 0.61 & 0.066 & 0.078 & 0.70 & 0.089 & 0.084 & 0.81 \\
\hline Proportion $+150 \mathrm{~m}^{2}$ & 0.013 & 0.011 & 0.68 & 0.007 & 0.006 & 0.88 & 0.021 & 0.019 & 0.91 \\
\hline \multicolumn{10}{|l|}{ Panel B. City-Level Attributes } \\
\hline Density $\left(\mathrm{km}^{2}\right)$ & 255.5 & $1,362.6$ & 0.01 & 110.1 & 484.3 & 0.31 & 530.2 & $1,224.8$ & 0.44 \\
\hline Crime (per $1,000 /$ inab.) & $2,784.5$ & $2,878.9$ & 0.76 & $2,223.3$ & $2,623.4$ & 0.28 & $2,833.9$ & $3,045.6$ & 0.76 \\
\hline Poverty $(\%)$ & 15.0 & 18.5 & 0.01 & 17.7 & 19.9 & 0.32 & 12.0 & 17.5 & 0.05 \\
\hline Waste Disposal (\%) & 0.202 & 0.244 & 0.14 & 0.217 & 0.217 & 0.26 & 0.218 & 0.257 & 0.47 \\
\hline \# of Parks (p.c.) & 0.125 & 0.082 & 0.25 & 0.104 & 0.052 & 0.22 & 0.299 & 0.074 & 0.01 \\
\hline \# of Public Squares (p.c.) & 4.087 & 0.754 & 0.09 & 12.266 & 0.752 & 0.02 & 1.023 & 0.754 & 0.36 \\
\hline
\end{tabular}

Notes: Matching using 1:1 nearest-neighbor matching procedure that requires an exact match for all the categorical variables. p.c. $=$ per capita.

Table 3: Balance Table of Mean Pre-Treatment (2011) Characteristics After NearestNeighbor Matching

comparisons in Table 2. After shrinking the control group to only comparable houses, there is no strong evidence that pre-treatment observables are different among households in the 
treatments and in the control groups, particularly for variables in panel A. ${ }^{23}$

\subsection{Other Matching Procedures}

Three additional matching procedures are considered as a robustness check. A straightforward modification is to set the number of minimum matches, $m$, to be greater than one. This option means that each observation $h$ in the treatment group has a set of nearestneighbors of size $m>1$. A second modification sets the distance of continuous variables between treated observations and their matches, $\left\|\mathbf{H}_{\mathbf{h}}-\mathbf{H}_{\mathbf{k}}\right\| s$, to be less or equal than a constant $c$ called the caliper, while the third modification considers the Euclidean distance matrix as the $\mathbf{S}$ distance matrix.

\section{Results}

\subsection{The Effects of Extraction Site Openings on Rental Prices}

Estimates of the effects of mine openings on rental prices are displayed in Table A6 (Appendix) for the spatial DID estimator, and in Table 4 for the spatial DIDNNM estimator. Panel A exhibits the results for all-mine openings, panel B for only conventional openings, and panel $\mathrm{C}$ for only artisanal mine openings. Columns (1) to (6) represent different specifications of equation 4 .

The results in Table A6 (Appendix) on the impacts of proximity to the concentration of new mines are all negative, an indication that these openings lead to a decrease in the rental prices of nearby houses. In other words, increasing health risks and social and environmental degradation from mining, requires renters to be compensated with lower rental prices to

\footnotetext{
${ }^{23}$ Figure A5 (Appendix) displays the common trends assumption for all the treatments and the placebo group using the matched sample. Relative to the trends in rental prices exhibited for the baseline sample (Figure A4), the price gap between homes in treated and control cities shrinks once the comparability of the control group is improved. At the same time, there is a new price trend in cities with all-mine openings (panel a) and artisanal mine openings (panel c). Pre-treatment common trends on the matched sample suggest the existence of a negative treatment effect for all the three different treatments.
} 
attract them to these places. Yet, a concern on these results is that houses in treatment and control groups are not directly comparable, as revealed previously in Table 2, which could bias the estimates in Table A6. This concern is minimized after estimating the hedonic price equation on the matched sample in Table 4, which offer a more relievable overview of the impact of mining on rental prices.

\begin{tabular}{|c|c|c|c|c|c|c|}
\hline & $(1)$ & $(2)$ & $(3)$ & $(4)$ & $(5)$ & (6) \\
\hline \multicolumn{7}{|c|}{ Panel A. All-Mine Openings: } \\
\hline $1[T] \times 1[$ After $]$ & $\begin{array}{l}-0.265 \\
(0.203)\end{array}$ & $\begin{array}{c}-0.104^{* *} \\
(0.049)\end{array}$ & $\begin{array}{c}-0.172^{* *} \\
(0.058)\end{array}$ & $\begin{array}{c}-0.198^{* * *} \\
(0.054)\end{array}$ & $\begin{array}{c}-0.191^{* * *} \\
(0.046)\end{array}$ & $\begin{array}{r}-0.207^{* * *} \\
(0.054)\end{array}$ \\
\hline $\mathrm{N}$ treated & 2,212 & 2,212 & 2,212 & 2,200 & 2,200 & 2,200 \\
\hline $\mathrm{N}$ control & 3,663 & 3,663 & 3,663 & 3,604 & 3,604 & 3,604 \\
\hline \multicolumn{7}{|c|}{ Panel B. Only Conventional Openings: } \\
\hline $1[T] \times 1[$ After $]$ & $\begin{array}{l}-0.183 \\
(0.112)\end{array}$ & $\begin{array}{c}-0.180^{*} \\
(0.102)\end{array}$ & $\begin{array}{c}-0.218^{*} \\
(0.112)\end{array}$ & $\begin{array}{c}-0.196^{*} \\
(0.106)\end{array}$ & $\begin{array}{l}-0.167^{*} \\
(0.0947)\end{array}$ & $\begin{array}{l}-0.160 \\
(0.110)\end{array}$ \\
\hline $\mathrm{N}$ treated & 231 & 231 & 231 & 229 & 229 & 229 \\
\hline $\mathrm{N}$ control & 270 & 270 & 270 & 254 & 254 & 254 \\
\hline \multicolumn{7}{|c|}{ Panel C. Only Artisanal Openings: } \\
\hline $1[T] \times 1[$ After $]$ & $\begin{array}{l}-0.341 \\
(0.259)\end{array}$ & $\begin{array}{c}-0.150^{* *} \\
(0.062)\end{array}$ & $\begin{array}{c}-0.168^{* *} \\
(0.053)\end{array}$ & $\begin{array}{c}-0.192^{* *} \\
(0.074)\end{array}$ & $\begin{array}{c}-0.194^{* *} \\
(0.061)\end{array}$ & $\begin{array}{c}-0.221^{* * *} \\
(0.040)\end{array}$ \\
\hline $\mathrm{N}$ treated & 770 & 770 & 770 & 770 & 770 & 770 \\
\hline N control & 1,697 & 1,697 & 1,697 & 1,681 & 1,681 & 1,681 \\
\hline Controls & & $\times$ & $\times$ & $\times$ & $\times$ & $\times$ \\
\hline Air and Water Pollution & & & & $\times$ & $\times$ & $\times$ \\
\hline Region FE & & $x$ & & & $x$ & \\
\hline Region $\times$ Year FE & & & $x$ & & & $x$ \\
\hline
\end{tabular}

Notes: Using rental prices in logs as the response variable. Matching on every period using 1:1 nearestneighbor matching procedure that requires an exact match for all the categorical variables included in the original hedonic-price estimation. Controls include house-level characteristics and city-level attributes described in Table 3. Air and water pollution variables are the z-scores of their respective pollution indexes. Standard errors clustered by region in parentheses. Significance levels: ${ }^{*} p<0.10,{ }^{* *} p<0.05,{ }^{* * *} p<0.001$.

Table 4: The Impact of Mine Openings on Rental Prices: Spatial DIDNNM

As shown in Table 4, the estimated causal effects of new mines remain negative after redefining the control group. Overall, the results in Table 4 suggest that the concentration of new mines represents an environmental disamenity to households. The DIDNNM estimator in column (1) shows that households are compensated with rental prices that are 27 percent lower in cities with all-mine openings (panel A), 18 percent lower in cities with conventional openings (panel B), and 34 percent lower in cities with artisanal mine openings (panel C). 
These effects decrease in magnitude once the hedonic framework is introduced in columns (2)-(3). Proximity to the concentration of all-mine openings lowers rental prices in around 10-17 percent (panel A), while conventional openings decrease rental prices by roughly 1822 percent (panel B), although these last effects are weakly significant, particularly when the pollution indexes are included in columns (4)-(6). In fact, this inclusion in columns (4)-(6) decreases the magnitude of the negative net impact of conventional openings (panel B), suggesting that the impact of this type of mining is mostly linked to their pollution potential. This effect is weakly significant, however, probably because of the high local economic impacts of large and medium-scale mines (Aragon and Rud, 2013; Loayza and Rigolini, 2016), which could offset to a larger extent their disamenity effect.

The above is not necessarily the case of artisanal mining. As previously mentioned, artisanal mines are generally at a disadvantage relative to conventional mines regarding their compliance with current environmental laws and the use of safety practices. In addition, their local economic benefits tend to be smaller than large-scale operations due to their minor and sporadic operations. Consistently, the results in panel $\mathrm{C}$ indicate that artisanal openings decrease rental prices by around 15-17 percent (columns (2)-(3)). Moreover, this impact is even higher in magnitude after controlling for air and water pollution in columns (4)(6), suggesting that additional forms of distortions beyond air and water pollution, such as visual or soil pollution, social disruptions, or even concerns about future environmental disasters, are all relevant to this type of mining. Notwithstanding, under the concern that environmental variables might not be good controls, the preferred estimates are those in column (3) of Table 4.

To better understand this previous impact, Figure 2 shows the short-term rental price impact by the number of new conventional mines (panel a) and new artisanal mines (panel b). From this Figure, it is clear that the impact of new mining activity described in Table 4 is exacerbated as the number of new mines increases, yet with interesting contrasts. Panel (a) of Figure 2 shows that a reduced number of new mines leads to lower rental prices, 


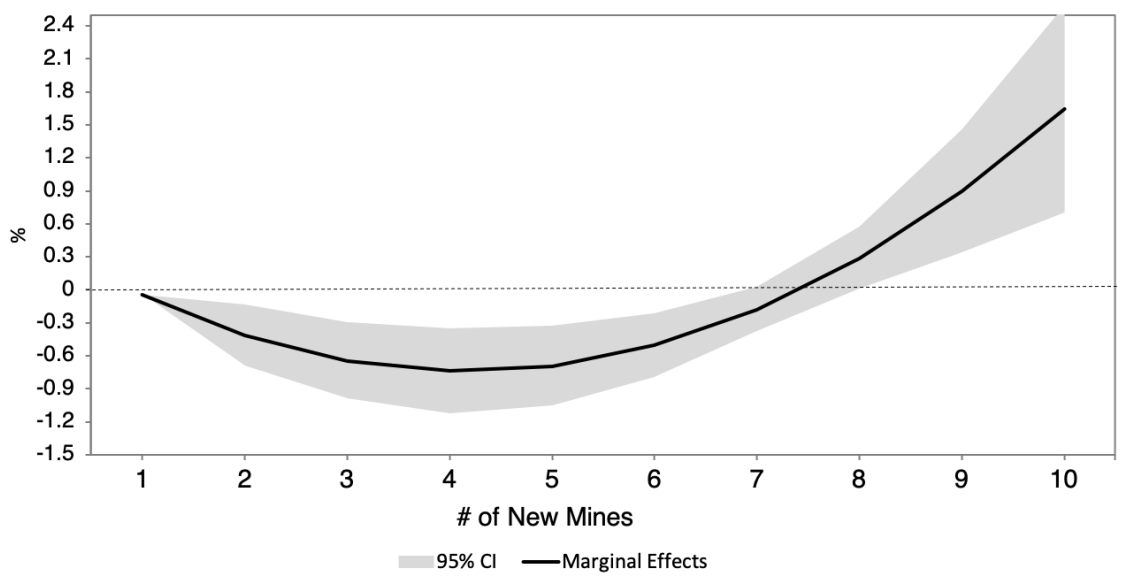

(a) Only Conventional Openings

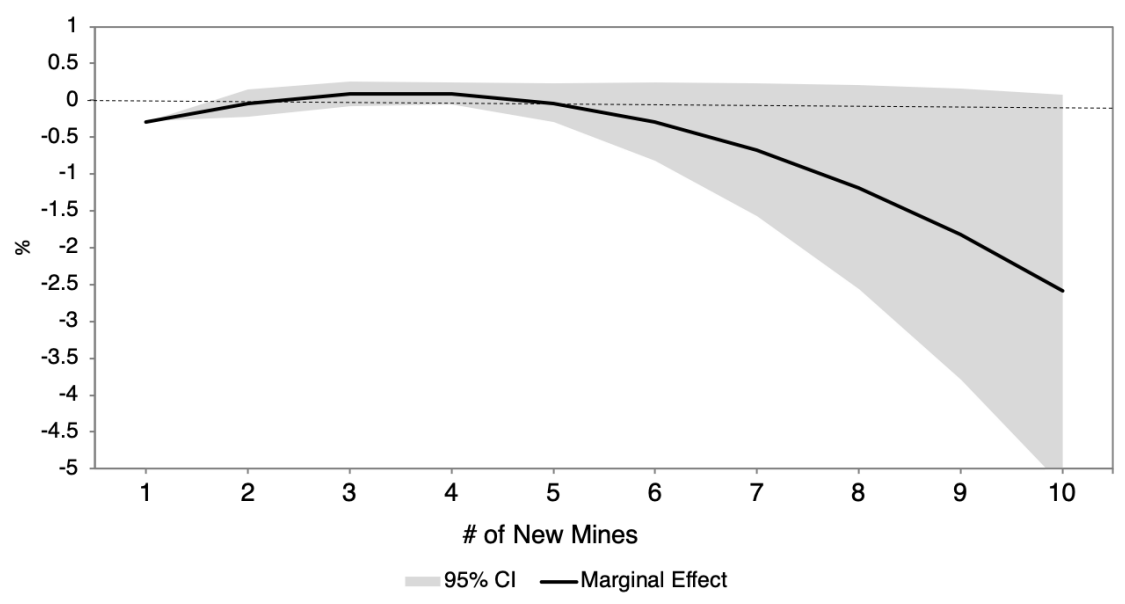

(b) Only Artisanal Openings

Figure 2: The Impact of Mine Openings on Rental Prices by Number of Openings

Notes: Non-linear effects are estimated using the specification in column (3) of Table 4 with a polynomial of degree two.

although this effect turns positive as the number of these new sites increases. As anticipated before, conventional openings generate a higher economic impact at the local level that counterbalance, to a higher extent, the negative externalities of extraction. As the number of these facilities increases, they attract more workers to these cities boosting the local economy and so the rental market, which can eventually lead to an increase in rental prices. ${ }^{24}$ In contrast, artisanal openings lead to a consistent reduction in rental prices (panel

\footnotetext{
${ }^{24}$ This is consistent with the house price index developed for Chile in Paredes and Aroca (2008). After matching houses across the entire country, they conclude that the region with the highest index is the region
} 
b), which is intensified as the number of these openings increases. Artisanal openings are small-scale deposits that employ a reduced, and less qualified number of workers, relative to conventional openings, and so new mines of this kind are unlikely to affect the inflow of migrants to these areas. Simultaneously, their operations are mostly focused around the extraction of the mineral (instead of smelting it), while institutional oversight mechanisms on their environmental impact are less clear. These two features could lead to a notorious concentration of pollution in areas hosting these openings, and so to a higher risk of future environmental disasters. For instance, the use of mills (trapiches) to reduced minerals to dust, is a common practice among artisanal miners in Chile (Sánchez and Enríquez, 1996), which in addition to exacerbating dust pollution increases noise and visual contamination. These factors outweigh the limited economic impact of this type of mining, leading ultimately to a sharp reduction in rental prices.

\subsection{Heterogeneous Effects by Pollution Levels}

This section explores whether the impact of opening new mines changes with different levels of environmental degradation. ${ }^{25}$ Table 5 displays the results for the air pollution index and for different levels of fine particle matter $\left(\mathrm{PM}_{2.5}\right)$ and sulfur dioxide $\left(\mathrm{SO}_{2}\right)$, while Table 6 exhibits similar results for the water pollution index and total suspended particles (TSS). ${ }^{26}$

Table 5 shows that the net negative effects of new mining activity vary with air pollution levels. The result for the air pollution index in the richest specification (column (3)) indicates a baseline negative impact on rental prices of 13 percent in cities with all-mine openings (panel A) and an additional 16 percent price drop for a one standard-deviation increase in air pollution. This suggests that the greater the degree of airborne contamination, the higher the amount that households are willing to pay to avoid mining. This result holds even after replacing the air pollution index with $\mathrm{PM}_{2.5}$ or $\mathrm{SO}_{2}$ emissions. The results in Table $\mathrm{A} 7$ for that has had the highest number of conventional mines over time.

${ }^{25}$ The goal of this section is to study heterogeneous effects of mining on rental prices at different degrees of environmental pollution, regardless of the origin or source of this pollution.

${ }^{26}$ Results for the other air pollutants are in Table A7 in the Appendix. 


\begin{tabular}{|c|c|c|c|c|c|c|c|c|c|}
\hline & \multicolumn{3}{|c|}{ Air Pollution Index } & \multicolumn{3}{|c|}{$\mathrm{PM}_{2.5}$} & \multicolumn{3}{|c|}{$\mathrm{SO}_{2}$} \\
\hline & (1) & $(2)$ & (3) & (1) & $(2)$ & $(3)$ & (1) & $(2)$ & $(3)$ \\
\hline \multicolumn{10}{|l|}{ Panel A. All-Mine Openings: } \\
\hline $1[T] \times 1[$ After $]$ & $\begin{array}{c}-0.041 \\
(0.067)\end{array}$ & $\begin{array}{c}-0.131^{* *} \\
(0.054)\end{array}$ & $\begin{array}{c}-0.128^{* *} \\
(0.063)\end{array}$ & $\begin{array}{c}-0.111^{*} \\
(0.059)\end{array}$ & $\begin{array}{c}-0.181^{* * *} \\
(0.048)\end{array}$ & $\begin{array}{c}-0.191^{* * *} \\
(0.052)\end{array}$ & $\begin{array}{c}-0.082 \\
(0.060)\end{array}$ & $\begin{array}{c}-0.166^{* * *} \\
(0.046)\end{array}$ & $\begin{array}{c}-0.171^{* *} \\
(0.053)\end{array}$ \\
\hline $1[T] \times 1[$ After $] \times$ Pollution & $\begin{array}{c}-0.155^{* *} \\
(0.058)\end{array}$ & $\begin{array}{c}-0.123^{* *} \\
(0.042)\end{array}$ & $\begin{array}{c}-0.158^{* * *} \\
(0.041)\end{array}$ & $\begin{array}{c}-0.144^{* *} \\
(0.048)\end{array}$ & $\begin{array}{c}-0.205^{* * *} \\
(0.050)\end{array}$ & $\begin{array}{c}-0.201^{* * *} \\
(0.056)\end{array}$ & $\begin{array}{c}-0.041^{*} \\
(0.024)\end{array}$ & $\begin{array}{c}-0.081^{* * *} \\
(0.020)\end{array}$ & $\begin{array}{c}-0.080^{* * *} \\
(0.024)\end{array}$ \\
\hline \multicolumn{10}{|c|}{ Panel B. Only Conventional Openings: } \\
\hline $1[T] \times 1[$ After $]$ & $\begin{array}{c}-0.103 \\
(0.171)\end{array}$ & $\begin{array}{l}-0.045 \\
(0.136)\end{array}$ & $\begin{array}{l}-0.027 \\
(0.120)\end{array}$ & $\begin{array}{c}-0.028 \\
(0.120)\end{array}$ & $\begin{array}{c}0.024 \\
(0.125)\end{array}$ & $\begin{array}{c}0.067 \\
(0.128)\end{array}$ & $\begin{array}{c}-0.094 \\
(0.093)\end{array}$ & $\begin{array}{c}-0.077 \\
(0.106)\end{array}$ & $\begin{array}{c}0.007 \\
(0.106)\end{array}$ \\
\hline $1[T] \times 1[$ After $] \times$ Pollution & $\begin{array}{l}-0.117 \\
(0.189)\end{array}$ & $\begin{array}{c}-0.236^{*} \\
(0.139)\end{array}$ & $\begin{array}{c}-0.282^{* *} \\
(0.112)\end{array}$ & $\begin{array}{c}-0.162^{*} \\
(0.089)\end{array}$ & $\begin{array}{c}-0.262^{* *} \\
(0.087)\end{array}$ & $\begin{array}{c}-0.318^{* * *} \\
(0.067)\end{array}$ & $\begin{array}{c}-0.059^{*} \\
(0.033)\end{array}$ & $\begin{array}{c}-0.101^{* *} \\
(0.037)\end{array}$ & $\begin{array}{c}-0.131^{* * *} \\
(0.032)\end{array}$ \\
\hline \multicolumn{10}{|c|}{ Panel C. Only Artisanal Openings: } \\
\hline $1[T] \times 1[$ After $]$ & $\begin{array}{c}0.0358 \\
(0.100)\end{array}$ & $\begin{array}{c}-0.079 \\
(0.076)\end{array}$ & $\begin{array}{c}-0.137^{* *} \\
(0.045)\end{array}$ & $\begin{array}{c}-0.151 \\
(0.103)\end{array}$ & $\begin{array}{c}-0.148^{* *} \\
(0.074)\end{array}$ & $\begin{array}{c}-0.198^{* * *} \\
(0.037)\end{array}$ & $\begin{array}{c}-0.092 \\
(0.103)\end{array}$ & $\begin{array}{c}-0.213^{* *} \\
(0.087)\end{array}$ & $\begin{array}{c}-0.212^{* *} \\
(0.084)\end{array}$ \\
\hline $1[T] \times 1[$ After $] \times$ Pollution & $\begin{array}{c}-0.148 \\
(0.095)\end{array}$ & $\begin{array}{c}-0.169^{* *} \\
(0.063)\end{array}$ & $\begin{array}{l}-0.074 \\
(0.046)\end{array}$ & $\begin{array}{l}-7.616 \\
(4.933)\end{array}$ & $\begin{array}{c}-0.772 \\
(4.074)\end{array}$ & $\begin{array}{l}-0.119 \\
(2.113)\end{array}$ & $\begin{array}{c}-3.500^{* *} \\
(1.353)\end{array}$ & $\begin{array}{c}-4.722^{* *} \\
(2.140)\end{array}$ & $\begin{array}{l}-1.530 \\
(2.158)\end{array}$ \\
\hline Controls & $\times$ & $\times$ & $\times$ & $\times$ & $\times$ & $\times$ & $x$ & $\times$ & $\times$ \\
\hline Region FE & & $x$ & & & $x$ & & & $x$ & \\
\hline Region $\times$ Year FE & & & $\times$ & & & $\times$ & & & $x$ \\
\hline
\end{tabular}

Notes: Results for the DIDNNM estimator. Panel A: N treated $=2,200, \mathrm{~N}$ control $=3,604$. Panel B: N treated $=229, \mathrm{~N}$ control $=254$. Panel C: $\mathrm{N}$ treated $=770, \mathrm{~N}$ control $=1,681$. All regressions control for house-level characteristics and city-level attributes described in Table 3. Standard errors clustered by region in parentheses. Significance levels: ${ }^{*} p<0.10,{ }^{* *} p<0.05,{ }^{* * *} p<0.001$.

Table 5: The Impact of Mine Openings by Air Pollution Levels

$\mathrm{NO}_{X}$ confirm this result.

A similar conclusion is found for conventional openings (panel B), although the baseline impact of mine openings turns insignificant this time. In this scenario, rental prices drop only with increased contamination, as reflected by the significance of the interaction between $1[T] \times 1[$ After $]$ and the air pollution index. The results for $\mathrm{PM}_{2.5}$ are also found negative and high in magnitude, potentially due to the high correlation that exists - at large-scale operations - between this pollutant and other harmful contaminants such as $\mathrm{SO}_{2}$ (also significant). In this situation, the interaction between $1[T] \times 1[$ After $]$ and $\mathrm{PM}_{2.5}$ emissions would be capturing airborne deteriorations due to other pollutants as well, which increases the magnitude of this estimate. In any case, the negative impact of conventional openings in areas with high air quality deterioration is reinforced across all the different airborne pollutants. ${ }^{27}$ On the contrary, artisanal mine openings (panel C) maintain a strong baseline

\footnotetext{
${ }^{27}$ Strong heterogeneous effects are found for CO emissions in Table A7 as well. CO is one of the most common airborne pollutants from vehicle emissions. Large- and medium-scale operations in Chile are known
} 
negative effect on rental prices that is only weakly aggravated by air pollution.

\begin{tabular}{|c|c|c|c|c|c|c|}
\hline & \multicolumn{3}{|c|}{ Water Pollution Index } & \multicolumn{3}{|c|}{ TSS } \\
\hline & (1) & $(2)$ & $(3)$ & (1) & $(2)$ & $(3)$ \\
\hline \multicolumn{7}{|l|}{ Panel A. All-Mine Openings: } \\
\hline $1[T] \times 1[$ After $]$ & $\begin{array}{c}-0.237^{* * *} \\
(0.045)\end{array}$ & $\begin{array}{c}-0.221^{* *} \\
(0.058)\end{array}$ & $\begin{array}{c}-0.294^{* * *} \\
(0.061)\end{array}$ & $\begin{array}{l}-0.082 \\
(0.063)\end{array}$ & $\begin{array}{c}-0.191^{* * *} \\
(0.051)\end{array}$ & $\begin{array}{c}-0.153^{* *} \\
(0.055)\end{array}$ \\
\hline $1[T] \times 1[$ After $] \times$ Pollution & $\begin{array}{c}-0.147^{* * *} \\
(0.020)\end{array}$ & $\begin{array}{l}-0.030 \\
(0.088)\end{array}$ & $\begin{array}{l}-0.101 \\
(0.077)\end{array}$ & $\begin{array}{l}-0.004 \\
(0.002)\end{array}$ & $\begin{array}{c}0.002 \\
(0.002)\end{array}$ & $\begin{array}{c}-0.028^{* *} \\
(0.009)\end{array}$ \\
\hline \multicolumn{7}{|c|}{ Panel B. Only Conventional Openings: } \\
\hline $1[T] \times 1[$ After $]$ & $\begin{array}{c}0.187 \\
(0.105)\end{array}$ & $\begin{array}{c}0.184 \\
(0.112)\end{array}$ & $\begin{array}{c}0.139 \\
(0.105)\end{array}$ & $\begin{array}{l}-0.142 \\
(0.105)\end{array}$ & $\begin{array}{l}-0.127 \\
(0.114)\end{array}$ & $\begin{array}{l}-0.109 \\
(0.110)\end{array}$ \\
\hline $1[T] \times 1[$ After $] \times$ Pollution & $\begin{array}{c}-0.993^{* * *} \\
(0.146)\end{array}$ & $\begin{array}{c}-0.762^{* * *} \\
(0.150)\end{array}$ & $\begin{array}{c}-0.709^{* *} \\
(0.156)\end{array}$ & $\begin{array}{c}-0.013^{*} \\
(0.008)\end{array}$ & $\begin{array}{c}-0.022^{* *} \\
(0.007)\end{array}$ & $\begin{array}{c}-0.028^{* * *} \\
(0.005)\end{array}$ \\
\hline \multicolumn{7}{|c|}{ Panel C. Only Artisanal Openings: } \\
\hline $1[T] \times 1[$ After $]$ & $\begin{array}{c}-0.268^{* *} \\
(0.074)\end{array}$ & $\begin{array}{c}-0.260^{* *} \\
(0.064)\end{array}$ & $\begin{array}{c}-0.363^{* *} \\
(0.078)\end{array}$ & $\begin{array}{c}0.077 \\
(0.064)\end{array}$ & $\begin{array}{c}-0.023 \\
(0.062)\end{array}$ & $\begin{array}{l}-0.104 \\
(0.065)\end{array}$ \\
\hline $1[T] \times 1[$ After $] \times$ Pollution & $\begin{array}{c}-0.298^{*} \\
(0.150)\end{array}$ & $\begin{array}{l}-0.149 \\
(0.140)\end{array}$ & $\begin{array}{l}-0.313 \\
(0.265)\end{array}$ & $\begin{array}{c}-0.165^{* * *} \\
(0.041)\end{array}$ & $\begin{array}{c}-0.147^{* * *} \\
(0.041)\end{array}$ & $\begin{array}{c}-0.103^{* *} \\
(0.043)\end{array}$ \\
\hline Controls & $\times$ & $\times$ & $\times$ & $\times$ & $\times$ & $\times$ \\
\hline Region FE & & $\times$ & & & $\times$ & \\
\hline Region $\times$ Year FE & & & $\times$ & & & $\times$ \\
\hline
\end{tabular}

Notes: Results for the DIDNNM estimator. All regressions control for house-level characteristics and citylevel attributes described in Table 3. Panel A: $\mathrm{N}$ treated $=2,194, \mathrm{~N}$ control $=3,604$. Panel B: $\mathrm{N}$ treated $=$ $229, \mathrm{~N}$ control $=254$. Panel C: $\mathrm{N}$ treated $=764, \mathrm{~N}$ control $=1,681$. Standard errors clustered by region in parentheses. Significance levels: ${ }^{*} p<0.10,{ }^{* *} p<0.05,{ }^{* * *} p<0.001$.

Table 6: The Impact of Mine Openings by Water Pollution Levels

Regarding water pollution, the results in panel B of Table 6 suggest that new conventional mines generates a zero baseline impact on rental prices, yet this effect becomes significant in areas with high levels of water pollution. The result for the water pollution index in column (3) indicates that rental prices decrease by $70 \%$ in cities hosting new conventional mining activity whenever the water pollution index increases by one standard deviation. This result holds after replacing this index with TSS, although it shows a significant decrease in magnitud, potentially due to a disparity between subjective perceptions of water pollution and the TSS. ${ }^{28}$ For artisanal openings (panel C) and the water pollution index, the results

for their high reliance on pickup trucks for their operations, as they facilitate the transportation of workers and equipment across different facilities (Paredes and Rivera, 2017). Hence, it is not surprising that a high concentration of this type of mines could also boost $\mathrm{CO}$ emissions and other harmful pollutants from vehicle emissions. This could also explain the high magnitude of the estimates on $\mathrm{PM}_{2.5}$.

${ }^{28}$ Limited households' awareness regarding recreational water pollution, and the irrelevance of this characteristic when it comes to households' location decisions (Boyle and Kiel, 2001), might explain the disparity 
suggest a negative but insignificant effect. When this index is replaced with the TSS metric, artisanal mine openings show a strong 10-17\% decrease on rental prices for a one unit increase in water pollution. The lack of significant results of artisanal openings and air pollution in Table 5, together with the insignificant baseline impact of these openings in Table 6 once the TSS is included, are presumably indicating that the detrimental impact of artisanal openings on rental prices is mostly related to water contamination.

\subsection{Heterogeneous Effects by Type of Residents}

The answer to whether mining is an environmental disamenity is conditional on whether individuals sort across space based on their preferences for environmental quality. With this type of sorting, rent compensations due to poor environmental quality might not be homogeneous in areas exposed to pollution as some of their residents would downplay the disamenity effect from the resource extraction. To test this idea, households of treated and control cities are split into old and new residents, and their results displayed in Table $7 .{ }^{29}$

Estimates in Table 7 indicate that old residents of areas with new mines are willing to pay more to avoid this activity than new residents. These results are strongly statistically significant, except for residents of cities with new conventional openings where the sample size is smaller. In the preferred estimations (column (3)), old residents of cities with general openings are willing to pay 8 percent more than new residents to avoid this activity (panel A), and $7 \%$ to avoid new artisanal activity (panel C). These results are a strong indication that residents new to mining tows might have a lower sensitivity to environmental degradation. ${ }^{30}$ In this case, the results in Table 4 (and A6) represent an average rent gradient, averaged

\footnotetext{
between subjective reports on water pollution and more objective indicators.

${ }^{29}$ Households in 2015 CASEN report their 2010 city of residence, which defines people as either old residents (i.e. households living in their current city for at least five years), or new residents (i.e. households that during the last five years moved into their current city).

${ }^{30}$ Another explanation is that newcomers, due to their recent relocation, might not be fully aware of the environmental and social changes affecting their neighborhoods. Even when this is a possibility, some of the disparities observed in Tables 5 and 6 between objective and subjective measures of environmental pollution reinforce the idea that some households may be indifferent to environmental degradation.
} 
across different subgroups of population. ${ }^{31}$

\begin{tabular}{|c|c|c|c|c|c|c|}
\hline & (1) & $(2)$ & (3) & $(4)$ & (5) & (6) \\
\hline \multicolumn{7}{|l|}{ Panel A. All-Mine Openings: } \\
\hline $1[T] \times 1[$ After $]$ & $\begin{array}{c}-0.382^{* *} \\
(0.149)\end{array}$ & $\begin{array}{r}-0.157^{* *} \\
(0.073)\end{array}$ & $\begin{array}{c}-0.221^{* * *} \\
(0.060)\end{array}$ & $\begin{array}{c}-0.247^{* * *} \\
(0.068)\end{array}$ & $\begin{array}{c}-0.239^{* * *} \\
(0.053)\end{array}$ & $\begin{array}{c}-0.251^{* * *} \\
(0.062)\end{array}$ \\
\hline $1[T] \times 1[$ After $] \times 1[$ Old Resident $]$ & $\begin{array}{c}-0.341^{* * *} \\
(0.044)\end{array}$ & $\begin{array}{c}-0.100^{* *} \\
(0.035)\end{array}$ & $\begin{array}{c}-0.081^{* *} \\
(0.028)\end{array}$ & $\begin{array}{c}-0.097^{* *} \\
(0.033)\end{array}$ & $\begin{array}{c}-0.086^{* *} \\
(0.027)\end{array}$ & $\begin{array}{c}-0.085^{* *} \\
(0.028)\end{array}$ \\
\hline \multicolumn{7}{|l|}{ Panel B. Only Conventional Openings: } \\
\hline $1[T] \times 1[$ After $]$ & $\begin{array}{l}-0.194 \\
(0.202)\end{array}$ & $\begin{array}{l}-0.107 \\
(0.208)\end{array}$ & $\begin{array}{l}-0.243 \\
(0.201)\end{array}$ & $\begin{array}{l}-0.127 \\
(0.188)\end{array}$ & $\begin{array}{l}-0.186 \\
(0.191)\end{array}$ & $\begin{array}{l}-0.170 \\
(0.204)\end{array}$ \\
\hline $1[T] \times 1[$ After $] \times 1[$ Old Resident $]$ & $\begin{array}{l}-0.176 \\
(0.126)\end{array}$ & $\begin{array}{l}-0.038 \\
(0.148)\end{array}$ & $\begin{array}{c}-0.042 \\
(0.152)\end{array}$ & $\begin{array}{l}-0.035 \\
(0.150)\end{array}$ & $\begin{array}{l}-0.047 \\
(0.151)\end{array}$ & $\begin{array}{l}-0.049 \\
(0.153)\end{array}$ \\
\hline \multicolumn{7}{|l|}{ Panel C. Only Artisanal Openings: } \\
\hline $1[T] \times 1[$ After $]$ & $\begin{array}{l}-0.352 \\
(0.290)\end{array}$ & $\begin{array}{c}-0.149^{* *} \\
(0.058)\end{array}$ & $\begin{array}{c}-0.196^{* * *} \\
(0.048)\end{array}$ & $\begin{array}{c}-0.234^{* *} \\
(0.070)\end{array}$ & $\begin{array}{c}-0.229^{* * *} \\
(0.050)\end{array}$ & $\begin{array}{c}-0.246^{* * *} \\
(0.046)\end{array}$ \\
\hline $1[T] \times 1[$ After $] \times 1[$ Old Resident $]$ & $\begin{array}{c}-0.244^{* *} \\
(0.109)\end{array}$ & $\begin{array}{c}-0.071^{*} \\
(0.040)\end{array}$ & $\begin{array}{l}-0.064 \\
(0.039)\end{array}$ & $\begin{array}{l}-0.069^{*} \\
(0.039)\end{array}$ & $\begin{array}{c}-0.069^{*} \\
(0.037)\end{array}$ & $\begin{array}{c}-0.068^{*} \\
(0.040)\end{array}$ \\
\hline Controls & & $\times$ & $\times$ & $\times$ & $\times$ & $\times$ \\
\hline Air and Water Pollution & & & & $x$ & $x$ & $x$ \\
\hline Region FE & & $x$ & & & $x$ & \\
\hline Region $\times$ Year FE & & & $x$ & & & $x$ \\
\hline
\end{tabular}

Notes: Results for the DIDNNM estimator. Matching on every period using 1:1 nearest-neighbor matching procedure that requires now an exact match by type of resident. Controls include house-level characteristics and city-level attributes described in Table 3. Air and water pollution variables are the z-scores of their respective pollution indexes. Panel A: $\mathrm{N}$ treated $=2,200, \mathrm{~N}$ control $=3,604$. Panel B: $\mathrm{N}$ treated $=229$, $\mathrm{N}$ control $=254$. Panel C: $\mathrm{N}$ treated $=770, \mathrm{~N}$ control $=1,681$. Standard errors clustered by region in parentheses. Significance levels: ${ }^{*} p<0.10,{ }^{* *} p<0.05,{ }^{* * *} p<0.001$.

Table 7: The Impact of Mine Openings by Type of Resident

\subsection{Average Willingness-to-Pay Measures}

Monthly average willingness-to-pay measures (WTP) to avoid proximity to the concentration of mines are displayed in Table $8 .{ }^{32}$ These results reveal that households are willing to

\footnotetext{
${ }^{31}$ The fact that households can be split between old and new residents could indicate that estimations using only new residents would solve the issue of mobility costs common to hedonic applications as these new residents were recently part of an optimal decision process when moving. Inference regarding the equilibrium of these new residents, however, should also consider the hedonic wage function as these residents took their decision based not only on a rent-compensation but also on a wage-compensation (Roback, 1982). Results in Table 7 constitute preliminary evidence that new residents may have weaker preferences for environmental quality as they receive lower rent-compensations when moving to less pleasant areas. Yet, more comprehensive conclusions should be derived after estimating a hedonic wage function, which is outside the scope of this paper.

${ }^{32}$ As extraction sites are known to affect environmental quality and so to disrupt social activities, estimates in Table 8 constitute an overall measure of the local impact of mining that goes beyond air and water
} 
pay a premium to avoid proximity to the concentration of new mines, or in other words, that they are compensated for living in proximity to this activity. Particularly, renters are compensated monthly with roughly USD 30-62 for living near to new mining activity (equivalent to a $7-14 \%$ of the country's minimum wage). ${ }^{33}$ The higher premium (USD 62) takes place in areas with a concentration of artisanal mines, potentially because of the low local economic benefits of this activity, which are insufficient to offset its unintended negative effects. The results in Table 8 are expected to draw the attention of policy makers and regulators when it comes to the management of mining, particularly when it comes to small-scale and artisanal operations.

\begin{tabular}{lccc}
\hline \hline & $\begin{array}{c}\text { All-Mine } \\
\text { Openings }\end{array}$ & $\begin{array}{c}\text { Only Conventional } \\
\text { Openings }\end{array}$ & $\begin{array}{c}\text { Only Artisanal } \\
\text { Openings }\end{array}$ \\
\hline Avoid Proximity to Mines & $-47.2^{* *}$ & $-29.7^{* *}$ & $61.6^{* * *}$ \\
\hline
\end{tabular}

Notes: Calculations using estimates in column (3) of Table 4 for each of the treatments. Monthly rental price calculated with the total number of observations used in the estimation. Dollar value: $\mathrm{CH} \$ 700$. Standard errors calculated using the Delta Method. Significance levels: ${ }^{*} p<0.10,{ }^{* *} p<0.05,{ }^{* * *} p<0.001$.

Table 8: Average Willingness-to-Pay Measures (Monthly USD)

\subsection{Robustness Checks}

Previous results of the impact of mine openings on rental prices are robust to several other specifications. Table 9 displays the impact of opening either open-pit mines or underground mines as alternative treatments. Open-pit mining, or strip mining, is a surface mining technique that entails the extraction of vast amounts of the ore placed in the ground by their elimination from an open pit. Because the excavation remains open to the surface for the duration of the mine's life, open-pit sites generally feature large amounts of air pollution and dust, sound pollution, and ground vibration, increasing the likelihood of higher detrimental

\footnotetext{
degradation.

${ }^{33}$ Huang and Lanz (2018) derive a WTP of USD 40.50 for a unit reduction in $\mathrm{PM}_{10}$ in China. In 2018, China's GDP per capita (PPP) was USD 18,210.1, while Chile's was USD 25,283.9. Source: https: //data.worldbank.org
} 
effects on the environment than other mining techniques (Monjezi et al., 2009). Consistently, the results for the effect of open-pit mines in Table 9 (panel A) suggest that households are willing to pay more to avoid proximity to the concentration of open-pit mines. Findings for the richest specification (column (3)) indicate a relatively high effect; households near opencast mining are compensated with rental prices that are 38 percent lower. When compared to underground mining (panel B), the results suggest that the disamenity effect of proximity to open-cast mining is higher than to underground mining.

\begin{tabular}{lcccccc}
\hline \hline & $(1)$ & $(2)$ & $(3)$ & $(4)$ & $(5)$ & $(6)$ \\
\hline \multicolumn{2}{l}{ Panel A. Open-Pit Mining: } & & & & & \\
\hline $1[T] \times 1[$ After] & $-0.232^{*}$ & $-0.235^{* *}$ & $-0.380^{* *}$ & $-0.241^{* *}$ & $-0.324^{* *}$ & $-0.445^{* *}$ \\
& $(0.125)$ & $(0.109)$ & $(0.148)$ & $(0.114)$ & $(0.141)$ & $(0.153)$ \\
\multicolumn{2}{l}{ Panel B. Underground Mining: } & & & & & \\
\hline $1[T] \times 1[$ After] & -0.122 & -0.121 & $-0.152^{* *}$ & $-0.150^{*}$ & -0.105 & -0.129 \\
& $(0.122)$ & $(0.074)$ & $(0.069)$ & $(0.082)$ & $(0.094)$ & $(0.101)$ \\
Controls & & $\times$ & $\times$ & $\times$ & $\times$ & $\times$ \\
Air and Water Pollution & & & & $\times$ & $\times$ & $\times$ \\
Region FE & & & & $\times$ & \\
Region $\times$ Year FE & & & $\times$ & & & $\times$ \\
\hline
\end{tabular}

Notes: Results for the DIDNNM estimator. Matching on every period using 1:1 nearest-neighbor matching procedure that requires now an exact match by type of resident. Controls include house-level characteristics and city-level attributes described in Table 3. Air and water pollution variables are the z-scores of their respective pollution indexes. Standard errors clustered by region in parentheses. Significance levels: ${ }^{*} p<$ $0.10,{ }^{* *} p<0.05,{ }^{* * *} p<0.001$.

Table 9: Robustness Check: The Impact of New Open-Pit and New Underground Mines

To rule out the possibility that the DIDNNM results are driven by the choice of the matching method, Table A8 (Appendix) displays the estimated causal effects but using different matching techniques. The results in Table A8 are all statistically significant and with the expected sign for all the different treatments. Rental prices are roughly 15-19 percent lower in areas around of all-mine openings (panel A), 24 percent lower in areas with conventional openings (panel B), and around 19-25 percent lower in areas with artisanal openings (panel C).

When lower rental prices in areas experiencing new mine openings are reflecting the disamenity effect of new mining activity, then areas with a constant number of mines should 
exhibit a price vector that shows no significant variations due to this feature when compared to control cities. Results for this falsification test are displayed in Table A9 (Appendix) using the placebo group of cities as the treatment group. The results show that the placebo effect on rental prices is not statistically different from zero, which constitutes strong evidence of the validity of the previous causal effects.

A final concern is that new mining activity is boosting new housing construction leading to depressed prices of the older rental housing stock. To rule out the possibility that estimated causal effects are merely reflecting a new housing price vector from a supply expansion, Table A10 (Appendix) displays the DID estimation results for the number of certificates of occupancy issued during the study period. Certificates of occupancy indicate whether new properties are in suitable conditions for occupancy after verified compliance with the applicable housing codes. Hence, their issuance represents a proxy of the stock of housing in each locality and for a given period. Findings for the average treatment effect of mine openings on the number of issued certificates are all statistically insignificant, irrespective of whether year 2015 or 2016 is considered. These results dismiss the possibility that a supply shock is affecting housing in treated cities relative to control cities, or in other words, that a new housing price vector is confounding identification. For the validity of this robustness exercise, an overview of the common trends assumption for the number of these certificates issued during pre-treatment years is displayed in Figure A6 (Appendix).

\subsection{Potential Threats to the Validity of the DID Estimates}

A valid concern on the previous results is that factors omitted from the analysis could bias the estimation. Unfortunately, the lack of data on alternative measures of resourcerichness (e.g. ore reserves), or the multiple extraction of different minerals from the same site, prevent the instrumentation of new site openings. Notwithstanding, this section discuss

the bias that could affect the results, and review some evidence that makes this possibility implausible. 
Former studies show that the location of unpleasant facilities might not follow a random process, and instead, be driven by the specific housing and demographic characteristics of certain neighborhoods (Davis, 2011; Muehlenbachs et al., 2013b, 2015). When the location of these facilities is not at random, correlated unobservables might confound identification of causal effects. While the location of new extraction sites is mostly determined by the exogenous geo-location of the resource, other variables such as resource booms or favorable economic conditions might still influence firms' decisions when considering opening a new site as well as rental prices. In that event, unobservables will affect the treatment and the outcome in the same direction, leading to upward biased estimates. Upward bias occurs when the estimate $\hat{\beta}$, is higher than the true parameter $\beta$, in which case the causal effect would be overestimated. Results in this study, however, show a strong evidence that the estimate of interest is less than zero, in which case $\beta<\hat{\beta}<0$. In other words, and even in the presence of upward biased estimates, statistically significant DID and DIDNNM estimates in this study are sufficient to show the significance of the true disamenity effect.

A different argument might suggest that both the DID and the DIDNNM could be downward biased as well. For instance, if the opening of polluting facilities occurs in cities with poorer economic conditions, omitted variables would then affect the probability of mine openings and rental prices in the opposite direction, biasing the estimates towards zero. In such case, statistically significant estimates are not enough to show the significance of the true effect. This situation, however, is ruled out by the DID specification that controls for time-constant unobservable factors common to either treated or control cities. Full results for the hedonic DID estimations (available upon request) show no statistically significant differences in pre-treatment rental prices among houses in treated and control cities. In fact, the common trends assumption in Figure A5 (Appendix) suggests that rental prices can be either lower (cities with conventional openings) or higher (cities with artisanal openings) than in control cities. Additionally, mineral resources in Chile are owned by the national government, as opposed to the U.S., where they are owned by private individuals. This 
implies that mining companies do not have to engage in leasing contracts with privates as a manner of initiating the extraction, which limits the ability of households with common susceptibilities towards the extraction process to affect the extraction decision. Finally, and despite the existence of a political committee that decides the mine's future in cases of social dispute with social or environmental movements, members of this committee respond directly to Chile's president, which minimizes the likelihood of local influence. ${ }^{34,35}$ To this date, this committee has mediated in only one opportunity, rejecting the project under consideration. ${ }^{36}$

One last concern is the existence of announcement effects. If people anticipate to the opening of a new mine, then the previous estimates constitute a lower bound of the true effect as some individuals may have already adjusted their expectations to a potential degradation in their neighborhoods. On the other hand, the possibility that current estimates could be reflecting expectations about future openings instead, is eliminated by the DID specification whenever these future expectations are common to places with current openings.

\section{Conclusions}

Millions of people live in countries rich in natural resources, but all too often they are exposed to heavy environmental and social impacts from their extraction. Despite previous studies having addressed some of the local economic impacts of extractive industries, this work is pioneering in providing an empirical understanding of the negative environmental and social aspects of these operations on the housing market. Using spatial and temporal variation in the concentration of new mines in Chile, this paper documents the existence of the massive negative net effects of the concentration of new extraction sites on rental market prices of residential properties. Results show that, on average, households are willing to pay

\footnotetext{
${ }^{34}$ Particularly, these members are the heads of the Ministries of Environment, of Mining, of Economics, of Energy, of Health, and of Agriculture, with the minister of Environment as the chair of the entire committee.

${ }^{35}$ Low levels of corruption in Chile minimize the possibility that bribery could be driving some of the results as well. Currently, Chile is second least corrupt country in Latin America, with a rank of 27/180 according to the Corruption Perception Index by Transparency International. Source: https://www.transparency. org/cpi2018

${ }^{36}$ Source: http://www.mining.com/chile-rejects-divisive-2-5-billion-dominga-copper-iron-project
} 
between 30 and 62 USD to avoid proximity to the concentration of mines, which represents a 7-14\% of the country's legal minimum wage. Further analyses show that this compensation is more significant in areas with high air and water quality degradation, and among longterm residents of mining areas. The fact that new residents of mining counties are willing to accept lower rental compensations suggests a preference-based sorting of households across space.

Previous studies on the local impact of digging activities are generally focused on local labor market effects, poverty levels, and real income effects, with little guidance on the negative externalities of extraction. This study shows empirical evidence of the economic relevance of these aspects, mostly for individuals who could be constrained to move away from this activity. Omitting the heavy environmental and social impacts from digging activities could therefore lead to misleading conclusions regarding the social benefits of this industry, particularly in settings where many of these sites are left abandoned after operations cease increasing the risks of accidents and/or environmental disasters. One of the main contributions of this paper is to provide evidence, framed in a causality design, that this activity represents indeed an environmental and social disamenity to nearby residents. Additionally, this study shows the need for more attentiveness around the social welfare effects of extractive industries in future research that quantify the impacts of mining, particularly in places with a heavy economic reliance on this activity.

This study can be improved in several ways. Data availability on residential properties that were sold during the treatment period could provide insights into the long-term effects of mine openings. Access to rental prices for more than two periods could also help to understand whether the negative impacts of mining persist over time. Finally, full access to the geo-location of residential properties could bring to light whether the net negative effects of mining dissipate with distance to the extraction sites. 


\section{References}

Angrist, J. D. and Pischke, J.-S. (2008). Mostly Harmless Econometrics: An Empiricist's Companion. Princeton University Press.

Aragon, F. M. and Rud, J. P. (2013). Natural Resources and Local Communities: Evidence From a Peruvian Gold Mine. American Economic Journal: Economic Policy, 5(2):1-25.

Arias, M., Atienza, M., and Cademartori, J. (2013). Large mining enterprises and regional development in chile: between the enclave and cluster. Journal of Economic Geography, $14(1): 73-95$.

Arimah, B. C. (1996). Willingness to pay for improved environmental sanitation in a nigerian city. Journal of Environmental management, 48(2):127-138.

Aroca, P. (2001). Impacts and development in local economies based on mining:: the case of the chilean ii region. Resources Policy, 27(2):119-134.

Aroca, P. and Atienza, M. (2011). Economic Implications of Long-Distance Commuting in the Chilean Mining Industry. Resources Policy, 36(3):196-203.

Bebbington, A., Bebbington, D. H., Bury, J., and Lingan, J. (2008). Mining and Social Movements: Struggles over Livelihood and Rural Territorial Development in the Andes. World Development, 36(12):2888-2905.

Berezansky, B., Portnov, B., and Barzilai, B. (2010). Objective vs. Perceived Air Pollution as a Factor of Housing Pricing: A Case Study of the Greater Haifa Metropolitan Area. Journal of Real Estate Literature, 18(1):99-122.

Blundell, R. and Dias, M. C. (2009). Alternative Approaches to Evaluation in Empirical Microeconomics. Journal of Human Resources, 44(3):565-640. 
Boslett, A., Guilfoos, T., and Lang, C. (2016). Valuation of expectations: A hedonic study of shale gas development and new york's moratorium. Journal of Environmental Economics and Management, 77:14-30.

Boxall, P. C., Chan, W. H., and McMillan, M. L. (2005). The impact of oil and natural gas facilities on rural residential property values: a spatial hedonic analysis. Resource and Energy Economics, 27(3):248-269.

Boyle, M. and Kiel, K. (2001). A Survey of House Price Hedonic Studies of the Impact of Environmental Externalities. Journal of Real Estate Literature.

Broner, F., Bustos, P., and Carvalho, V. (2012). Sources of Comparative Advantage in Polluting Industries. Technical report, National Bureau of Economic Research, Cambridge, MA, Cambridge, MA.

Bross, I. (1958). How to Use Ridit Analysis. Biometrics, 14(1):18-38.

Bulte, E. H., Damania, R., and Deacon, R. T. (2005). Resource intensity, institutions, and development. World development, 33(7):1029-1044.

Castro, S. H. and Sánchez, M. (2003). Environmental viewpoint on small-scale copper, gold and silver mining in chile. Journal of Cleaner Production, 11(2):207-213.

Chakroborty, U. K. and Narayan, B. (2014). Socio-economic issues and dilemmas of mining induced displacement: A case of coal mining industry. Journal of Economic $\mathcal{G}$ Social Development, 10(2).

Chasco, C. and Gallo, J. L. (2013). The Impact of Objective and Subjective Measures of Air Quality and Noise on House Prices: A Multilevel Approach for Downtown Madrid. Economic Geography, 89(2):127-148.

Chasco, C. and Le Gallo, J. (2015). Heterogeneity in Perceptions of Noise and Air Pollution: 
A Spatial Quantile Approach on the City of Madrid. Spatial Economic Analysis, 10(3):317343.

Chay, K. Y. and Greenstone, M. (2005). Does Air Quality Matter? Evidence from the Housing Market. Journal of Political Economy, 113(2):376-424.

COCHILCO (2016). Propiedad Minera en Chile: Estado y Medidas de Perfeccionamiento. Retrieved from https://www.cochilco.cl.

Consejo Minero (2017). Minería en Números. Retrieved from https://consejominero.cl/ apdm/mineria-en-chile/.

Currie, J., Davis, L., Greenstone, M., and Walker, R. (2015). Environmental Health Risks and Housing Values: Evidence from 1,600 Toxic Plant Openings and Closings. The American Economic Review, 105(2):678-709.

Davis, L. W. (2011). The Effect of Power Plants on Local Housing Values and Rents . Review of Economics and Statistics, 93(4):1391-1402.

De Gregori, I., Fuentes, E., Rojas, M., Pinochet, H., and Potin-Gautier, M. (2003). Monitoring of Copper, Arsenic and Antimony Levels in Agricultural Soils Impacted and NonImpacted by Mining Activities, from Three Regions in Chile. Journal of Environmental Monitoring, 5(2):287-295.

Dehejia, R. H. and Wahba, S. (2012). Causal Effects in Nonexperimental Studies: Reevaluating the Evaluation of Training Programs. Journal of the American Statistical Association.

Delgado, M. S., Guilfoos, T., and Boslett, A. (2016). The cost of unconventional gas extraction: A hedonic analysis. Resource and Energy Economics, 46:1-22.

Deng, G., Hernandez, M. A., and Xu, S. (2014). When Power Plants Leave Town: Environmental Quality and the Housing Market in China. Available at SSRN 2502442. 
Díaz Tobar, J. C. (2015). Diseño de una estrategia de intervención basada en el desarrollo de capital humano para la minería artesanal.

Freeman, A. M. (1979). The Hedonic Price Approach to Measuring Demand for Neighborhood Characteristics. In Segal, D., editor, The Economics of Neighborhood, chapter 9, pages 191-217. Elsevier.

Freeman III, A. M., Herriges, J. A., and Kling, C. L. (2014). The Measurement of Environmental and Resource Values: Theory and Methods. Routledge.

Gamble, H. B. and Downing, R. H. (1982). Effects of Nuclear Power Plants on Residential Property Values. Journal of Regional Science, 22(4):457-478.

Gamper-Rabindran, S. and Timmins, C. (2013). Does Cleanup of Hazardous Waste Sites Raise Housing Values? Evidence of Spatially Localized Benefits. Journal of Environmental Economics and Management, 65(3):345-360.

Gopalakrishnan, S. and Klaiber, H. A. (2013). Is the shale energy boom a bust for nearby residents? evidence from housing values in pennsylvania. American Journal of Agricultural Economics, 96(1):43-66.

Graham, J., Irving, J., Tang, X., Sellers, S., Crisp, J., Horwitz, D., Muehlenbachs, L., Krupnick, A., and Carey, D. (2015). Increased traffic accident rates associated with shale gas drilling in pennsylvania. Accident Analysis \&6 Prevention, 74:203-209.

Greenstone, M. and Gallagher, J. (2008). Does Hazardous Waste Matter? Evidence from the Housing Market and the Superfund Program. The Quarterly Journal of Economics, 123(3):951-1003.

Greenstone, M. and Jack, B. K. (2015). Envirodevonomics: A Research Agenda for an Emerging Field. Journal of Economic Literature, 53(1):5-42. 
Gylfason, T. (2001). Nature, power and growth. Scottish Journal of Political Economy, $48(5): 558-588$.

Harrison Jr, D. and Rubinfeld, D. L. (1978). Hedonic housing prices and the demand for clean air. Journal of Environmental Economics and Management, 5(1):81-102.

Huang, X. and Lanz, B. (2018). The value of air quality in chinese cities: Evidence from labor and property market outcomes. Environmental and Resource Economics, 71(4):849-874.

Jacobsen, G. D. (2019). Who wins in an energy boom? evidence from wage rates and housing. Economic Inquiry, 57(1):9-32.

James, A. and Smith, B. (2017). There will be blood: Crime rates in shale-rich us counties. Journal of Environmental Economics and Management, 84:125-152.

Kemp, D., Bond, C. J., Franks, D. M., and Cote, C. (2010). Mining, Water and Human Rights: Making the Connection. Journal of Cleaner Production, 18(15):1553-1562.

Kiel, K. A. and McClain, K. T. (1995a). House Prices during Siting Decision Stages: The Case of an Incinerator from Rumor through Operation. Journal of Environmental Economics and Management, 28(2):241-255.

Kiel, K. A. and McClain, K. T. (1995b). The Effect of an Incinerator Siting on Housing Appreciation Rates. Journal of Urban Economics, 37(3):311-323.

Kitula, A. G. N. (2006). The Environmental and Socio-Economic Impacts of Mining on Local Livelihoods in Tanzania: A Case Study of Geita District. Journal of Cleaner Production, $14(3-4): 405-414$.

Kohlhase, J. E. (1991). The Impact of Toxic Waste Sites on Housing Values. Journal of Urban Economics, 30(1):1-26.

Kolstad, I. and Søreide, T. (2009). Corruption in natural resource management: Implications for policy makers. Resources Policy, 34(4):214-226. 
Komarek, T. and Cseh, A. (2017). Fracking and public health: Evidence from gonorrhea incidence in the marcellus shale region. Journal of Public Health Policy, 38(4):464-481.

Komarek, T. M. (2018). Crime and natural resource booms: Evidence from unconventional natural gas production. The Annals of Regional Science, pages 1-25.

Kuminoff, N. V., Parmeter, C. F., and Pope, J. C. (2010). Which Hedonic Models Can We Trust to Recover the Marginal Willingness to Pay for Environmental Amenities? Journal of Environmental Economics and Management, 60(3):145-160.

Loayza, N. and Rigolini, J. (2016). The Local Impact of Mining on Poverty and Inequality: Evidence from the Commodity Boom in Peru. World Development, 84(C):219-234.

Mason, C. F., Muehlenbachs, L. A., and Olmstead, S. M. (2015). The economics of shale gas development. Annu. Rev. Resour. Econ., 7(1):269-289.

Mehlum, H., Moene, K., and Torvik, R. (2006). Institutions and the resource curse. The Economic Journal, 116(508):1-20.

Mendelsohn, R., Hellerstein, D., Huguenin, M., Unsworth, R., and Brazee, R. (1992). Measuring Hazardous Waste Damages with Panel Models. Journal of Environmental Economics and Management, 22(3):259-271.

Mendelsohn, R. and Olmstead, S. (2009). The Economic Valuation of Environmental Amenities and Disamenities: Methods and Applications. Annual Review of Environment and Resources, 34:325-347.

Michael, H. J., Boyle, K. J., and Bouchard, R. (2000). Does the Measurement of Environmental Quality Affect Implicit Prices Estimated from Hedonic Models. Land Economics, $76(2): 283$.

Milu, V., Leroy, J., and Peiffert, C. (2002). Water Contamination Downstream from a Copper Mine in the Apuseni Mountains, Romania. Environmental Geology, 42(7):773-782. 
Ministerio de Desarrollo Social (2009). Encuesta de Caracterización Socioeconómica Nacional CASEN. Retrieved from http://observatorio.ministeriodesarrollosocial. gob.cl/casen/basededatos_historico.php. Accessed: 2016-03-01.

Ministerio de Desarrollo Social (2011). Encuesta de Caracterización Socioeconómica Nacional CASEN. Retrieved from http://observatorio.ministeriodesarrollosocial. gob.cl/casen/basededatos_historico.php. Accessed: 2016-03-01.

Ministry of Environment (2011). Official Environment Status Report. Retrieved from http: //mma.gob.cl.

Monjezi, M., Shahriar, K., Dehghani, H., and Namin, F. S. (2009). Environmental impact assessment of open-pit mining in iran. Environmental Geology, 58(1):205-216.

Muehlenbachs, L., Spiller, E., and Timmins, C. (2013a). Shale Gas Development and the Costs of Groundwater Contamination Risk. SSRN Electronic Journal.

Muehlenbachs, L., Spiller, E., and Timmins, C. (2013b). Shale gas development and the costs of groundwater contamination risk. Resources for the Future Discussion Paper, (12-40).

Muehlenbachs, L., Spiller, E., and Timmins, C. (2015). The Housing Market Impacts of Shale Gas Development. The American Economic Review, 105(12):3633-59.

Muehlenbachs, L., Staubli, S., and Chu, Z. (2017). The accident externality from trucking. Technical report, National Bureau of Economic Research.

Newbold, J. (2006). Chile's environmental momentum: Iso 14001 and the large-scale mining industry-case studies from the state and private sector. Journal of Cleaner Production, $14(3-4): 248-261$.

Palmquist, R. B. (1992). Valuing Localized Externalities. Journal of Urban Economics, $31(1): 59-68$. 
Papke, L. E. and Wooldridge, J. (1996). Econometric methods for fractional response variables with an application to 401 (k) plan participation rates. Journal of Applied Econometrics, 11:619?632.

Paredes, D. and Aroca, P. (2008). Metodología para estimar un índice regional de costo de vivienda en chile. Cuadernos de economía, 45(131):129-143.

Paredes, D. and Rivera, N. M. (2017). Mineral taxes and the local public goods provision in mining communities. Resources Policy, 53:328-339.

Pegg, S. (2006). Mining and poverty reduction: Transforming rhetoric into reality. Journal of Cleaner Production, 14(3-4):376-387.

Petrova, S. and Marinova, D. (2013). Social impacts of mining: Changes within the local social landscape. Rural Society, 22(2):153-165.

Ridker, R. G. (1967). Economic Costs of Air Pollution, Studies in Measurement. Frederick A. Praeger, Publishers, New York.

Ridker, R. G. and Henning, J. A. (1967). The Determinants of Residential Property Values with Special Reference to Air Pollution. The Review of Economics and Statistics, $49(2): 246$.

Rivera, N. and Aroca, P. (2014). Escalas de producción en economías mineras: El caso de chile en su dimensión regional. EURE (Santiago), 40(121):247-270.

Roback, J. (1982). Wages, Rents, and the Quality of Life. The Journal of Political Economy, 90(6):1257-1278.

Robinson, J. A., Torvik, R., and Verdier, T. (2006). Political foundations of the resource curse. Journal of Development Economics, 79(2):447-468.

Rosen, K. T. and Smith, L. B. (1983). The price-adjustment process for rental housing and the natural vacancy rate. The American Economic Review, 73(4):779-786. 
Rosen, S. (1974). Hedonic Prices and Implicit Markets: Product Differentiation in Pure Competition. The Journal of Political Economy, 82(1):34-55.

Sánchez, J. M. and Enríquez, S. M. (1996). Impacto Ambiental de la Pequeña y Mediana Minería en Chile. Technical report, Universidad de Chile.

SERNAGEOMIN (2013). Concesiones Mineras de Exploracion y Explotacion Total Pais (\%). http://www.sernageomin.cl/pdf/mineria/estadisticas/estadisticas $\% 20 \mathrm{de} \%$ 20concesiones\%20mineras/propiedad_minera_2_2013.pdf. Accessed: 2017-07-17.

SINIM (2017). Datos Municipales. Retrieved from http://datos.sinim.gov.cl. Accessed: 2017-08-10.

Transparency International (2018). Riesgos de corrupción en concesiones mineras y otorgamiento de permisos ambientales: el caso de Chile. Retrieved from http:// www.chiletransparente.cl/wp-content/files_mf/1517340532InformeMineriafull. compressed.pdf.

Urkidi, L. (2010). A Glocal Environmental Movement Against Gold Mining: Pascua-Lama in Chile. Ecological Economics, 70(2):219-227.

U.S. Environmental Protection Agency (2013). America's Children and the Environment. Retrieved from https://www.epa.gov/sites/production/files/2015-06/documents/ ace3_2013.pdf.

USGS (2014). Minerals Yearbook - Chile. Retrieved from https://minerals.usgs.gov/ minerals/pubs/country/2014/myb3-2014-ci.pdf.

Weber, J. G. (2012). The effects of a natural gas boom on employment and income in colorado, texas, and wyoming. Energy Economics, 34(5):1580-1588.

Williams, A. M. (2011). The impact of surface coal mining on residential property values: A hedonic price analysis. 
World Bank (2018a). Chile Overview. Retrieved from https://www.worldbank.org/en/ country/chile/overview.

World Bank (2018b). Extractive Industries Overview. Retrieved from https://www. worldbank.org/en/topic/extractiveindustries/overview. 


\section{A. Appendix}

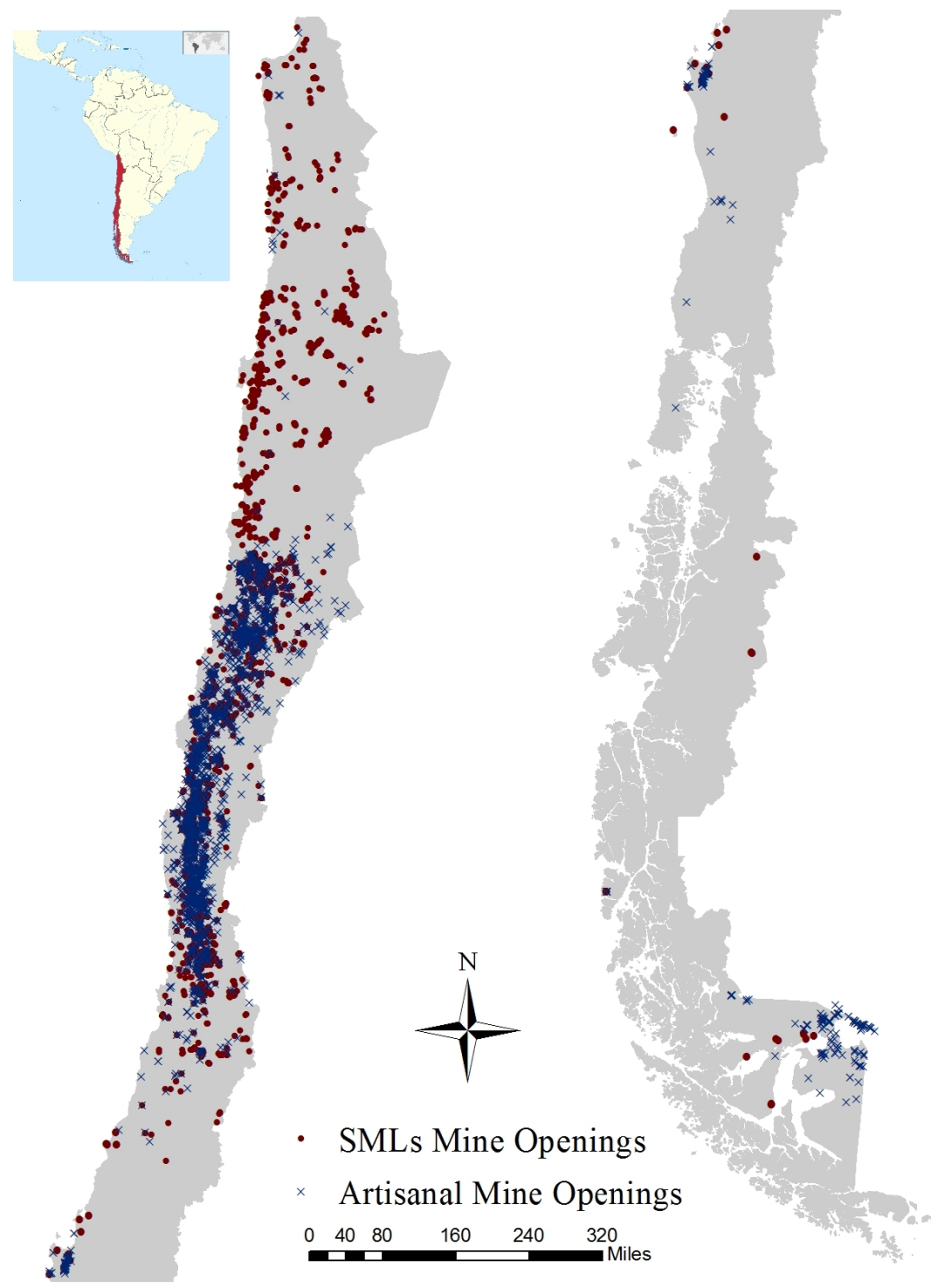

Notes: The ores extracted are mostly copper, silver, gold, zinc, iodine, lithium, molybdenum, natural nitrates, and rhenium. Sites plotted with ArcMap ${ }^{\circledR} 10.1$ using information from SERNAGEOMIN, Online, accessed May 12, 2016. Red dots symbolize conventional site openings and blue dots are for Artisanal sites.

Figure A1: Resource Extraction Site Openings Between 2011-2016 
2011

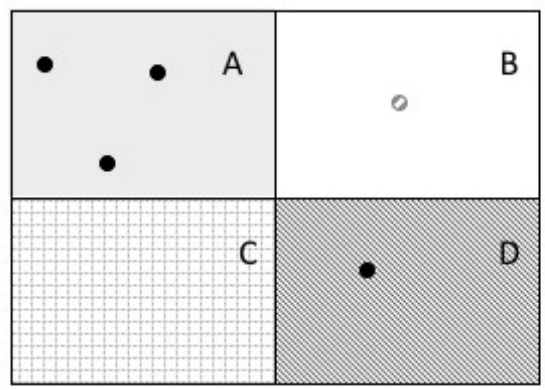

$=$ Cities

- = SMLs Mine

= Artisanal Mine
2016
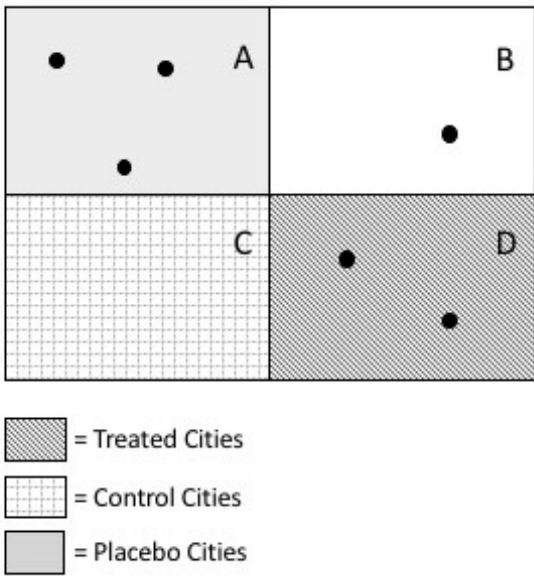

(a) Treated, Control, and Placebo Cities

2011

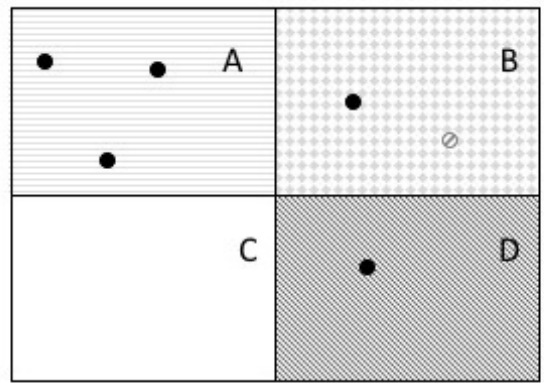

Treated Cities:

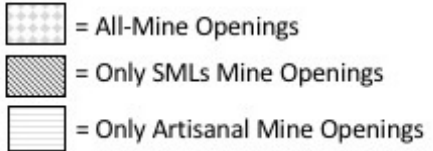

2016

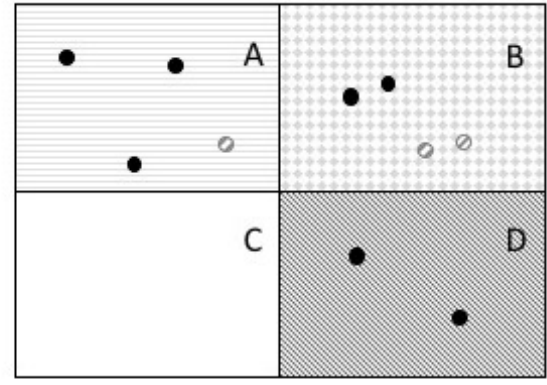

$=$ Control Cities

(b) Treatments Example

Notes: Panel (a) depicts different scenarios that allow the classification of cities as either treated, control, or placebo cities, or cities to dismiss from the analysis. Type-A cities are cities that over time have a constant number of mining sites, and so they are part of a placebo group of cities. Type-B cities are cities that over time experienced the closure and the opening of different types of mines, and therefore, they are dismissed from the analysis. Type-C cities are cities that for each year show no records of mine sitings. These cities belong to the control group of cities. Finally, type-D cities are cities that experienced the siting of a new mine, and therefore, they are part of a treated group of cities. Panel (b) displays the treatments considered in the analysis. Type-A cities are cities that host the opening of an artisanal mine only. Type-B cities are cities that host the opening of a new conventional mine and a new artisanal mine, that is, "all-mine openings". Type-C cities are control cities, while type-D cities are cities that host the opening of a conventional mine only.

Figure A2: Example of Treated, Control, and Placebo Cities, and Treatments 


\begin{tabular}{lcccc}
\hline \hline \multirow{2}{*}{ Type of Site } & \multicolumn{2}{c}{ Year } & \multicolumn{2}{c}{ Number of } \\
\cline { 2 - 5 } & 2011 & 2016 & Openings & Closings \\
\hline Conventional Sites & 1,324 & 4,093 & 3,537 & 768 \\
Open-Pit & 249 & 615 & 496 & 130 \\
Underground & 703 & 1,504 & 1,275 & 474 \\
Tailings & 58 & 634 & 593 & 17 \\
Others & 314 & 1,340 & 1,173 & 147 \\
Artisanal Sites & 3,920 & 3,590 & 2,943 & 3,273 \\
\hline Total & 5,244 & 7,683 & 6,480 & 4,041 \\
\hline
\end{tabular}

Notes: Other Conventional Sites include mineral processing sites and exploration deposits. Both Conventional and Artisanal Sites exclude administration facilities.

Table A1: Extraction Sites Over Time 


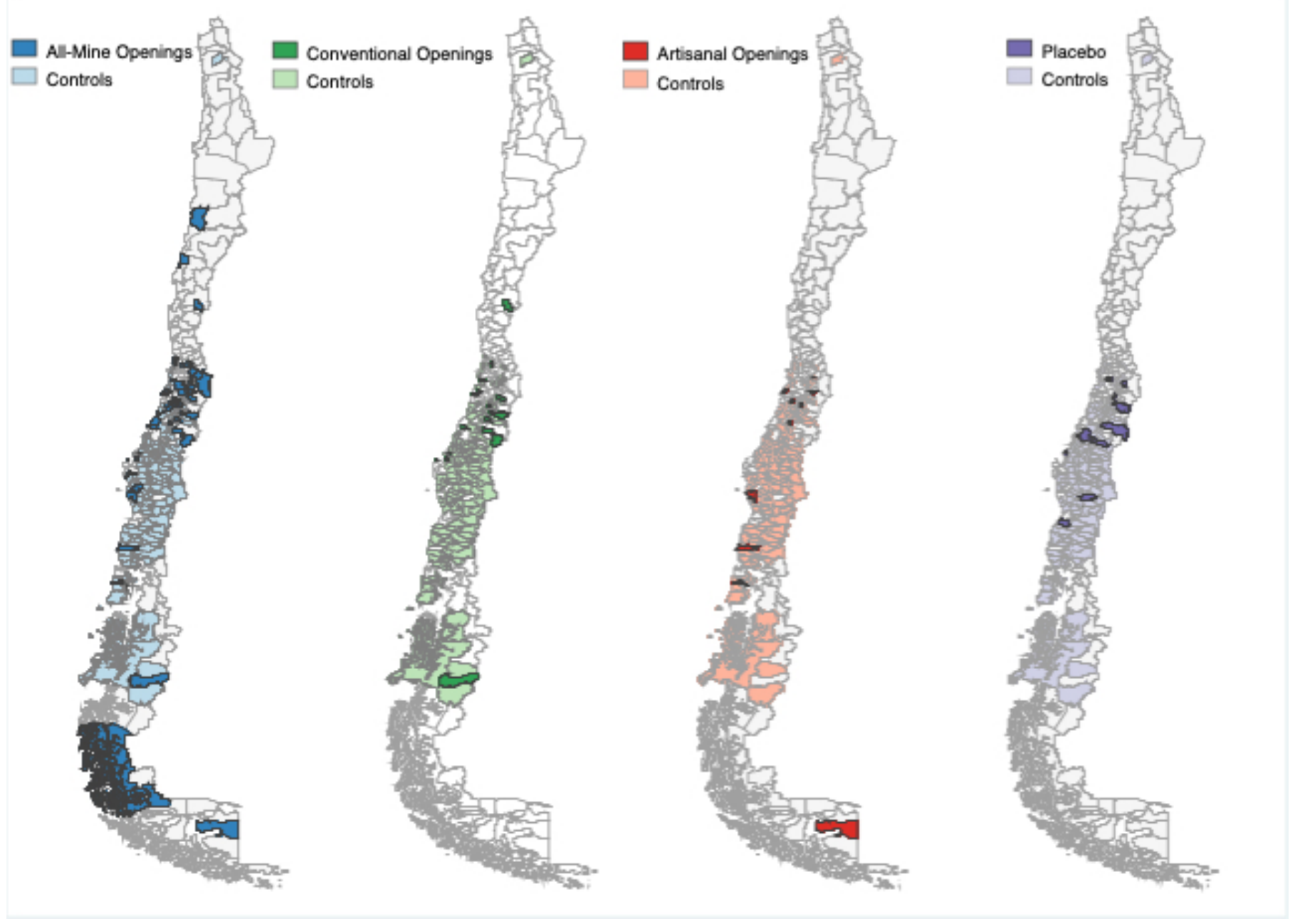

Figure A3: Overview of Treated, Control, and Placebo Cities 


\begin{tabular}{lcccc}
\hline \hline Variable & Mean & St. Dev. & Min. & Max. \\
\hline Rental Price & $135,590.1$ & $100,199.1$ & 10,000 & 790,000 \\
\# Bedrooms & 2.3 & 0.9 & 0 & 12 \\
\# Bathrooms & 1.2 & 0.5 & 0 & 6 \\
Dimension: & & & & \\
$\quad$ Less than 30m & 0.1 & 0.3 & 0 & 1 \\
$\quad$ Between 30-40m & 0.2 & 0.4 & 0 & 1 \\
$\quad$ Between 41-60m & 0.4 & 0.5 & 0 & 1 \\
$\quad$ Between 61-100m & 0.2 & 0.4 & 0 & 1 \\
$\quad$ Between 101-150m & 0.1 & 0.2 & 0 & 1 \\
$\quad$ More than 150m & 0.0 & 0.1 & 0 & 1 \\
Density (km ${ }^{2}$ & $3,039.6$ & $4,682.8$ & 0.42 & 17,145 \\
Crime (per 1,000/inab.) & $4,453.4$ & $4,110.4$ & 450 & 22,149 \\
Waste Disposal (\%) & 0.3 & 0.1 & 0 & 1 \\
Poverty (\%) & 15.7 & 8.8 & 0.2 & 60 \\
\# of Parks (p.c.) & 0.1 & 0.4 & 0 & 6 \\
\# of Public Squares (p.c.) & 1.4 & 5.9 & 0 & 136 \\
\hline N & & 13,687 & & \\
\hline
\end{tabular}

Notes: The crime variable considers criminal offenses of strong social connotation. p.c. $=$ per capita.

Table A2: Descriptive Statistics of Main Variables 


\begin{tabular}{lcccccc}
\hline \hline Variable & Category & $(1)$ & $(2)$ & $(3)$ & $(4)$ & $(5)$ \\
\hline \multirow{4}{*}{ Air Pollution } & Never & 7,913 & 3,957 & 0 & 3,957 & 0.3044 \\
& Few times & 2,578 & 1,289 & 7,913 & 9,202 & 0.7080 \\
& Frequently & 1,419 & 710 & 10,491 & 11,201 & 0.8617 \\
& Always & 1,088 & 544 & 11,910 & 12,454 & 0.9581 \\
& Total & 12,998 & & 12,998 & & \\
\hline \multirow{5}{*}{ Water Pollution } & Never & 11,533 & 5,767 & 0 & 5,767 & 0.4436 \\
& Few times & 753 & 377 & 11,533 & 11,910 & 0.9163 \\
& Frequently & 373 & 187 & 12,286 & 12,473 & 0.9596 \\
& Always & 339 & 170 & 12,659 & 12,829 & 0.9870 \\
& Total & 12,998 & & 12,998 & & \\
\hline
\end{tabular}

Notes: Based on Bross (1958), the approach assigns the continuous index number as half the share of the observations in each response category's upper and lower cumulative percentiles. For example, column (1) has the frequency distribution of the identified distribution. In this case, the identified distribution considers the national population of households renting a house. Column (2) has one-half of the corresponding entry in column (1). Column (3) has the cumulate of column (1) displaced one category upward. Column $(4)=$ column $(2)+$ column (3). Entries in column (5) represent the ridits equivalent to column (4) divided by grand total in (1).

Table A3: Ridits on Air and Water Pollution Perceptions 


\begin{tabular}{lccc}
\hline \hline Response Variable & Covariates & Coeff. & Std. Error \\
\hline \multirow{4}{*}{ Air Pollution $(\mathrm{N}=310)$} & $\mathrm{PM}_{25}$ & $0.411^{* *}$ & $(0.174)$ \\
& $\mathrm{CO}$ & $0.008^{*}$ & $(0.004)$ \\
& $\mathrm{NO}_{X}$ & 0.034 & $(0.074)$ \\
& $\mathrm{SO}_{2}$ & 0.032 & $(0.034)$ \\
\hline \multirow{3}{*}{ Water Pollution $(\mathrm{N}=311)$} & $\mathrm{TSS}$ & $-0.143^{* * *}$ & $(0.031)$ \\
& Streamflow & -0.067 & $(0.044)$ \\
& Density & $-0.004^{* * *}$ & $(0.001)$ \\
\hline
\end{tabular}

Notes: Results from a cross-section Bernoulli QMLE fractional logit regression for 2015 on cities' average pollution perceptions. p-values calculated using standard errors robust to a misspecification of the Bernoulli generalized linear model variance assumption. Variables on pollutant emissions are measured in thousand of tons/year. Streamflow refers to the regional monthly average streamflow of main rivers measured in L/seg. Density is measured in \#thousand of inab. $/ \mathrm{km}^{2}$

Table A4: Average Marginal Effects on Pollution Perceptions

Results in Table A4 for air pollution indicate that $\mathrm{PM}_{2.5}, \mathrm{CO}, \mathrm{NO}_{X}$, and $\mathrm{SO}_{2}$ emissions are all positively related with households' perceptions of bad air quality. In terms of water pollution perceptions, results indicate a counterintuitive sign for TSS. Regarding stream flow and cities' density, higher values for these variables are negatively related to water pollution perceptions. Higher stream flows nearby may be negatively related to water pollution perceptions because streams assimilative capacity (i.e. the stream capacity to reduce pollutant concentrations) increase with the streamflow magnitude. A higher population density, instead, might be negatively related to water pollution perceptions due to a lower variety of water reservoirs available for recreation in high dense areas, which might affect their perceptions on the contamination of these waterbodies. 


\begin{tabular}{lcccccc}
\hline \hline Variable & Period & Mean & Std. Dev. & Min & Max & N Cities \\
\hline \multirow{2}{*}{ Air Pollution } & 2011 & 0.527 & 0.082 & 0.469 & 0.996 & 345 \\
& 2015 & 0.474 & 0.116 & 0.307 & 0.959 & 310 \\
\hline \multirow{2}{*}{ Water Pollution } & 2011 & 0.528 & 0.012 & 0.482 & 0.539 & 293 \\
& 2015 & 0.509 & 0.074 & 0.442 & 0.958 & 311 \\
\hline
\end{tabular}

Table A5: Descriptive Statistics on Cities' Average Pollution Perceptions 


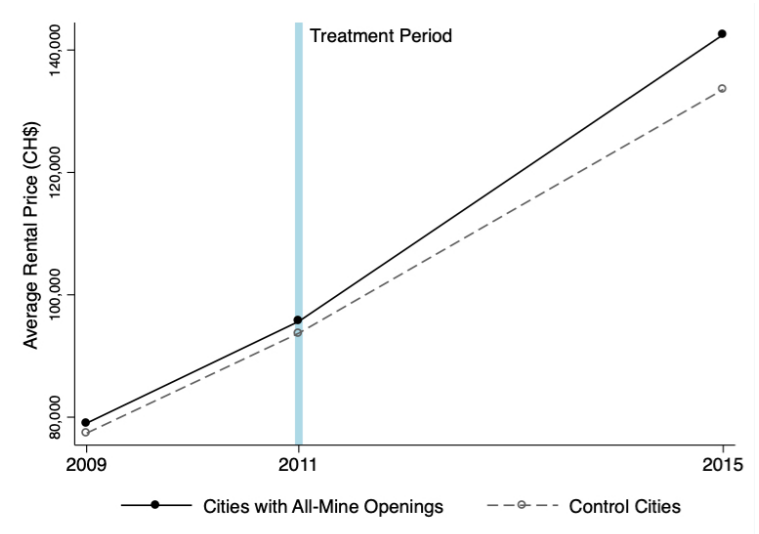

(a) All-Mine Openings

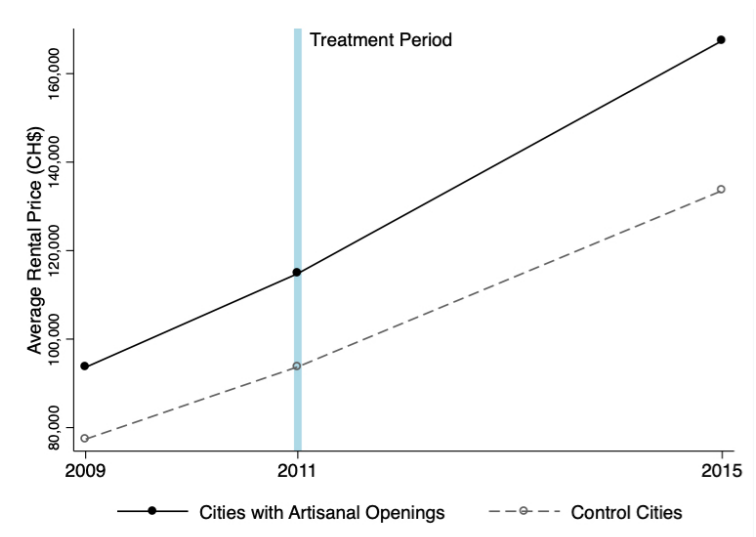

(c) Only Artisanal Openings

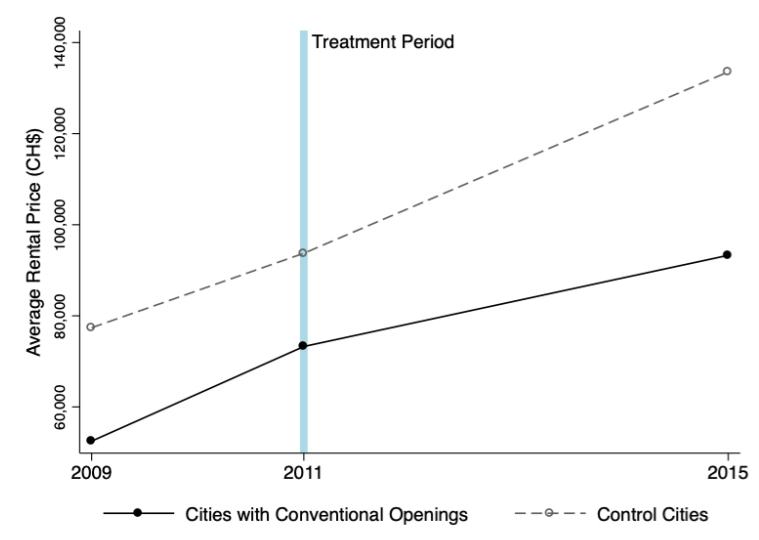

(b) Only Conventional Openings

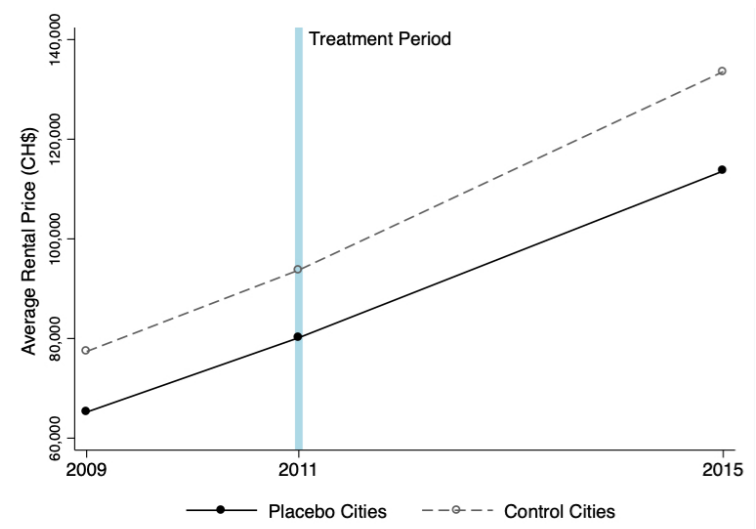

(d) Placebo Group

Notes: Considering tenants with a single family nucleus. Pre-treatment periods are 2009, and 2011, with information retrieved from Ministerio de Desarrollo Social $(2009,2011)$.

Figure A4: Overview of the Common Trends Assumption. Baseline Sample.

Two things from Figure A4 are worth mentioning. Overall, the common pre-treatment trends assumption fits the data well. Pre-treatment rental prices of homes in treated cities show a trend that is parallel to the one for homes in control cities for all the three treatments (panels a, b, and c) and for the placebo group (panel d). In addition, rental prices are higher in cities that host artisanal openings, a feature that is especially noteworthy because, as Section 6 shows, these are the openings that are strongly correlated with reductions in rental prices. A plausible explanation for this trend is the reduced comparability among houses in treated and control cities as shown in panel A of Table 2. 


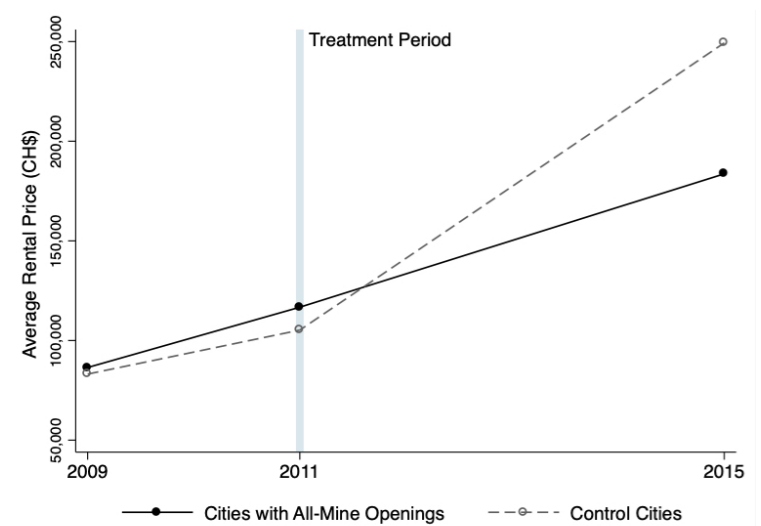

(a) All-Mine Openings

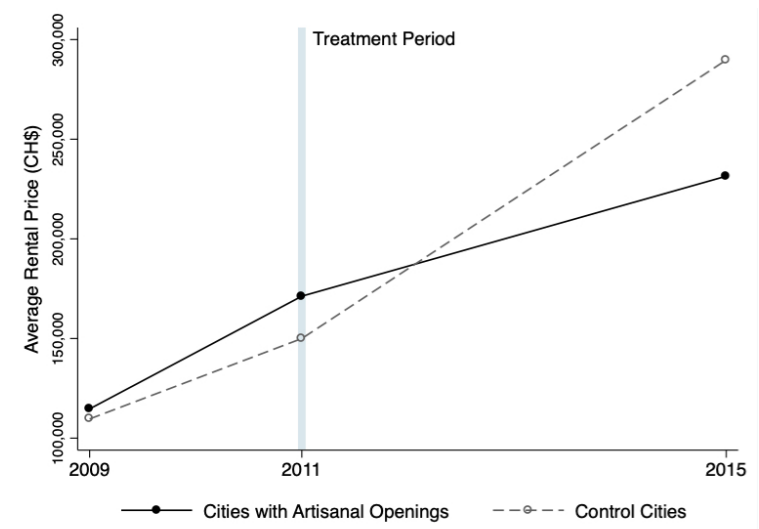

(c) Only Artisanal Openings

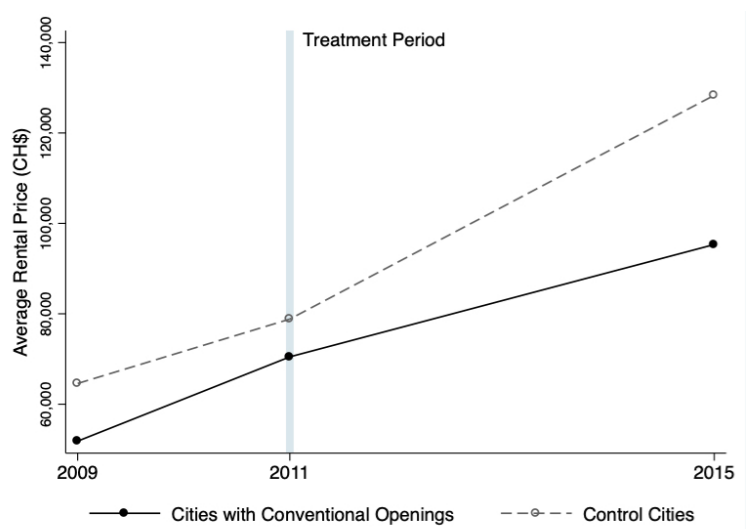

(b) Only Conventional Openings

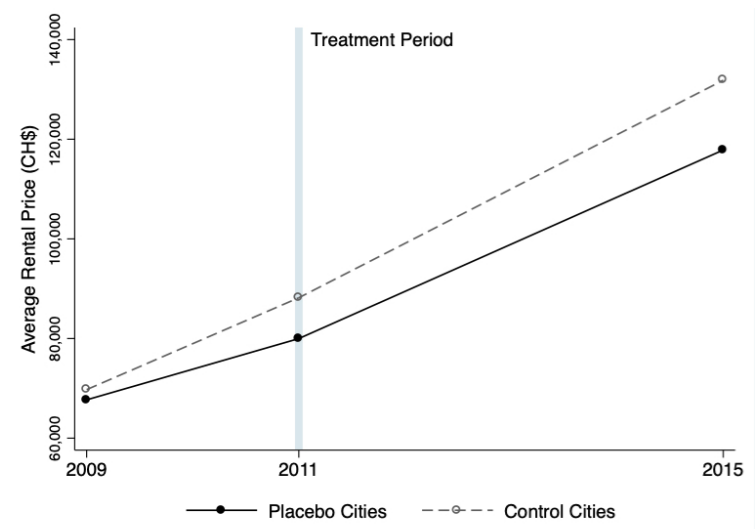

(d) Placebo Group

Notes: Considering tenants with a single family nucleus. Pre-treatment periods are 2009, and 2011, with information retrieved from Ministerio de Desarrollo Social $(2009,2011)$.

Figure A5: Overview of the Common Trends Assumption. Matched Sample.

Although pre-existing trends in rental prices are still common to homes in cities affected with the treatments and homes in the control group, the gap between these prices shrinks once units in the treatment groups are matched to comparable homes in the control group. Even more important is the change in these trends in cities affected with all-mine openings (panel a) and artisanal mine openings (panel c). A visual analysis of Figure A5 suggest a negative treatment effect in all cities treated with mine openings of any kind (panels a, b, and $\mathrm{c}$ ). 


\begin{tabular}{|c|c|c|c|c|c|c|}
\hline & (1) & $(2)$ & $(3)$ & $(4)$ & $(5)$ & (6) \\
\hline \multicolumn{7}{|c|}{ Panel A. All-Mine Openings: } \\
\hline $1[T] \times 1[$ After $]$ & $\begin{array}{l}-0.050 \\
(0.064)\end{array}$ & $\begin{array}{c}-0.063^{*} \\
(0.036)\end{array}$ & $\begin{array}{c}-0.114^{* *} \\
(0.051)\end{array}$ & $\begin{array}{c}-0.121^{* *} \\
(0.044)\end{array}$ & $\begin{array}{c}-0.129^{* *} \\
(0.040)\end{array}$ & $\begin{array}{c}-0.121^{* *} \\
(0.044)\end{array}$ \\
\hline $\mathrm{N}$ treated & 3,724 & 3,161 & 3,161 & 3,144 & 3,144 & 3,144 \\
\hline $\mathrm{N}$ control & 9,963 & 8,141 & 8,141 & 7,868 & 7,868 & 7,868 \\
\hline \multicolumn{7}{|c|}{ Panel B. Only Conventional Openings: } \\
\hline $1[T] \times 1[$ After $]$ & $\begin{array}{c}-0.185^{* *} \\
(0.090)\end{array}$ & $\begin{array}{c}-0.158^{*} \\
(0.087)\end{array}$ & $\begin{array}{c}-0.246^{* *} \\
(0.084)\end{array}$ & $\begin{array}{c}-0.259^{* *} \\
(0.084)\end{array}$ & $\begin{array}{c}-0.198^{* *} \\
(0.075)\end{array}$ & $\begin{array}{c}-0.259^{* *} \\
(0.084)\end{array}$ \\
\hline $\mathrm{N}$ treated & 394 & 306 & 306 & 301 & 301 & 301 \\
\hline $\mathrm{N}$ control & 9,963 & 8,141 & 8,141 & 7,868 & 7,868 & 7,868 \\
\hline \multicolumn{7}{|c|}{ Panel C. Only Artisanal Openings: } \\
\hline $1[T] \times 1[$ After $]$ & $\begin{array}{c}-0.033 \\
(0.080)\end{array}$ & $\begin{array}{c}-0.113 \\
(0.071)\end{array}$ & $\begin{array}{l}-0.119 \\
(0.086)\end{array}$ & $\begin{array}{c}-0.108^{*} \\
(0.056)\end{array}$ & $\begin{array}{c}-0.146^{* *} \\
(0.060)\end{array}$ & $\begin{array}{c}-0.108^{*} \\
(0.056)\end{array}$ \\
\hline $\mathrm{N}$ treated & 1,550 & 1,219 & 1,219 & 1,219 & 1,219 & 1,219 \\
\hline $\mathrm{N}$ control & 9,963 & 8,141 & 8,141 & 7,868 & 7,868 & 7,868 \\
\hline Controls & & $\times$ & $\times$ & $\times$ & $\times$ & $x$ \\
\hline Air and Water Pollution & & & & $\times$ & $\times$ & $x$ \\
\hline Region FE & & $\times$ & & & $x$ & \\
\hline Region $\times$ Year FE & & & $x$ & & & $x$ \\
\hline
\end{tabular}

Notes: Using rental prices in logs as the response variable. Controls include house-level characteristics and city-level attributes described in Table 2. Air and water pollution variables are the z-scores of their respective pollution indexes. Standard errors clustered by region in parentheses. Significance levels: ${ }^{*} p<0.10$, ${ }^{* *} p<0.05,{ }^{* * *} p<0.001$.

Table A6: The Impact of Mine Openings on Rental Prices: Spatial DID

Results in columns (1), (2) and (3) reveal that, on average, rental prices are 6-11 percent lower in cities that concentrate all-mine openings (panel A), around 19-25 percent lower in cities exposed to conventional openings (panel B), and around 11-12 percent lower in cities with artisanal mine openings (panel C). These results are statistically significant mostly for the richest specifications (column (3)). As expected, these impacts decrease in magnitude after the inclusion of the air and water pollution variables (indexes), particularly for all-mine openings and artisanal mine openings. On average, households are compensated with rental prices that are around 9-11 percent lower in cities with all-mine openings (panel A), around 18-26 percent lower in cities with conventional openings (panel B), and around 9-10 percent lower in cities with artisanal mine openings (panel C). All these estimates are statistically different from zero. 


\begin{tabular}{|c|c|c|c|c|c|c|}
\hline & \multicolumn{3}{|c|}{$\mathrm{CO}$} & \multicolumn{3}{|c|}{$\mathrm{NO}_{X}$} \\
\hline & $(1)$ & $(2)$ & $(3)$ & (1) & $(2)$ & (3) \\
\hline \multicolumn{7}{|l|}{ Panel A. All-Mine Openings: } \\
\hline $1[T] \times 1[$ After $]$ & $\begin{array}{c}-0.104^{*} \\
(0.058)\end{array}$ & $\begin{array}{c}-0.183^{* * *} \\
(0.049)\end{array}$ & $\begin{array}{c}-0.195^{* * *} \\
(0.053)\end{array}$ & $\begin{array}{l}-0.082 \\
(0.061)\end{array}$ & $\begin{array}{c}-0.169^{* * *} \\
(0.048)\end{array}$ & $\begin{array}{c}-0.176^{* *} \\
(0.055)\end{array}$ \\
\hline $1[T] \times 1[$ After $] \times$ Pollution & $\begin{array}{l}-0.016 \\
(0.026)\end{array}$ & $\begin{array}{l}-0.007 \\
(0.023)\end{array}$ & $\begin{array}{l}-0.009 \\
(0.023)\end{array}$ & $\begin{array}{l}-0.020 \\
(0.015)\end{array}$ & $\begin{array}{c}-0.048^{* * *} \\
(0.012)\end{array}$ & $\begin{array}{c}-0.050^{* * *} \\
(0.012)\end{array}$ \\
\hline \multicolumn{7}{|c|}{ Panel B. Only Conventional Openings: } \\
\hline $1[T] \times 1[$ After $]$ & $\begin{array}{l}-0.017 \\
(0.122)\end{array}$ & $\begin{array}{c}0.040 \\
(0.127)\end{array}$ & $\begin{array}{c}0.077 \\
(0.131)\end{array}$ & $\begin{array}{c}0.040 \\
(0.115)\end{array}$ & $\begin{array}{c}0.025 \\
(0.125)\end{array}$ & $\begin{array}{c}0.160 \\
(0.133)\end{array}$ \\
\hline $1[T] \times 1[$ After $] \times$ Pollution & $\begin{array}{l}-0.150^{*} \\
(0.082)\end{array}$ & $\begin{array}{c}-0.244^{* *} \\
(0.079)\end{array}$ & $\begin{array}{c}-0.293^{* * *} \\
(0.063)\end{array}$ & $\begin{array}{l}-0.033^{*} \\
(0.019)\end{array}$ & $\begin{array}{c}-0.057^{* *} \\
(0.022)\end{array}$ & $\begin{array}{c}-0.075^{* * *} \\
(0.016)\end{array}$ \\
\hline \multicolumn{7}{|c|}{ Panel C. Only Artisanal Openings: } \\
\hline $1[T] \times 1[$ After $]$ & $\begin{array}{c}-0.363^{* *} \\
(0.112)\end{array}$ & $\begin{array}{l}-0.152 \\
(0.127)\end{array}$ & $\begin{array}{c}-0.121 \\
(0.0740)\end{array}$ & $\begin{array}{c}0.100 \\
(0.170)\end{array}$ & $\begin{array}{l}-0.262^{*} \\
(0.154)\end{array}$ & $\begin{array}{l}-0.187 \\
(0.159)\end{array}$ \\
\hline $1[T] \times 1[$ After $] \times$ Pollution & $\begin{array}{c}0.141 \\
(0.089)\end{array}$ & $\begin{array}{c}0.016 \\
(0.064)\end{array}$ & $\begin{array}{l}-0.092 \\
(0.056)\end{array}$ & $\begin{array}{c}-0.619^{* * *} \\
(0.177)\end{array}$ & $\begin{array}{c}-0.524^{* * *} \\
(0.102)\end{array}$ & $\begin{array}{c}-0.864^{* *} \\
(0.391)\end{array}$ \\
\hline Controls & $\times$ & $\times$ & $\times$ & $\times$ & $\times$ & $\times$ \\
\hline Region FE & & $\times$ & & & $\times$ & \\
\hline Region $\times$ Year FE & & & $x$ & & & $\times$ \\
\hline
\end{tabular}

Notes: Results for the DIDNNM estimator. Matching on every period using 1:1 nearest-neighbor matching procedure that requires now an exact match by type of resident. Controls include house-level characteristics and city-level attributes described in Table 3. Standard errors clustered by region in parentheses. Significance levels: ${ }^{*} p<0.10,{ }^{* *} p<0.05,{ }^{* * *} p<0.001$.

Table A7: The Impact of Mine Openings by Air Pollution Levels: $\mathrm{CO}$ and $\mathrm{NO}_{X}$ 


\begin{tabular}{cccc}
\hline \hline & $\begin{array}{c}\text { Five } \\
\text { Neighbors }\end{array}$ & $\begin{array}{c}\text { Caliper } \\
(0.0001)\end{array}$ & $\begin{array}{c}\text { Euclidean } \\
\text { Distance }\end{array}$ \\
\cline { 2 - 4 } & $(1)$ & $(2)$ & $(3)$ \\
\hline Panel A. All-Mine Openings & & \\
$1[T] \times 1[$ After $]$ & $-0.148^{* *}$ & $-0.187^{* *}$ & $-0.179^{*}$ \\
& $(0.064)$ & $(0.056)$ & $(0.084)$ \\
$\mathrm{N}$ treated & 1,840 & 2,212 & 2,212 \\
$\mathrm{~N}$ control & 12,285 & 3,663 & 3,636 \\
Panel B. Only Conventional Openings & & \\
$1[T] \times 1[$ After] & $-0.241^{*}$ & -0.103 & $-0.241^{*}$ \\
& $(0.118)$ & $(0.142)$ & $(0.107)$ \\
$\mathrm{N}$ treated & 165 & 231 & 231 \\
$\mathrm{~N}$ control & 850 & 270 & 283 \\
Panel C. Only Artisanal Openings & & \\
$1[T] \times 1[$ After] & $-0.193^{* *}$ & $-0.252^{* * *}$ & $-0.244^{* *}$ \\
& $(0.039)$ & $(0.029)$ & $(0.050)$ \\
$\mathrm{N}$ treated & 763 & 770 & 770 \\
$\mathrm{~N}$ control & 6,263 & 1,697 & 1,697 \\
Controls & $\times$ & $\times$ & $\times$ \\
Air and Water Pollution & $\times$ & $\times$ & $\times$ \\
Region $\times$ Year FE & $\times$ & $\times$ & $\times$ \\
\hline
\end{tabular}

Notes: Matching on every period. All matching procedures require an exact match in all categorical variables included in the original hedonic-price estimation. Both Caliper and Euclidean distance matching require a 1:1 match. Standard errors clustered by region in parentheses. Significance levels: ${ }^{*} p<0.10$, ${ }^{* *} p<0.05,{ }^{* * *} p<0.001$.

Table A8: Robustness Check: Different Matching Procedures

\begin{tabular}{cccccccc}
\hline \hline & \multicolumn{2}{c}{ Original } & \multicolumn{5}{c}{ Matched Sample } \\
\cline { 3 - 8 } & \multicolumn{2}{c}{ Sample } & $\begin{array}{c}\text { One } \\
\text { Neighbor }\end{array}$ & $\begin{array}{c}\text { Five } \\
\text { Neighbor }\end{array}$ & Caliper & $\begin{array}{c}\text { Euclidean } \\
\text { Distance }\end{array}$ \\
\hline 1 Placebo] $\times 1$ [After] & -0.026 & -0.046 & -0.078 & -0.131 & -0.091 & -0.131 & -0.032 \\
& $(0.032)$ & $(0.052)$ & $(0.055)$ & $(0.084)$ & $(0.074)$ & $(0.084)$ & $(0.042)$ \\
N placebo & 972 & 972 & 759 & 759 & 481 & 759 & 759 \\
N control & 8,592 & 8,592 & 868 & 868 & 2,439 & 868 & 927 \\
Region FE & $\times$ & & $\times$ & & & & \\
Region $\times$ Year FE & & $\times$ & & $\times$ & $\times$ & $\times$ & $\times$ \\
\hline
\end{tabular}

Notes: Control variables and pollution indexes are included in all the specifications. Matching on every period. All matching procedures require an exact match in all categorical variables included in the original hedonic-price estimation. Both Caliper and Euclidean distance matching require a 1:1 match. Standard errors clustered by region in parentheses. Significance levels: ${ }^{*} p<0.10,{ }^{* *} p<0.05,{ }^{* * *} p<0.001$.

Table A9: Robustness Check: Placebo Group 


\begin{tabular}{lcccccc}
\hline \hline & \multicolumn{2}{c}{$\begin{array}{c}\text { All-Mine } \\
\text { Openings }\end{array}$} & \multicolumn{2}{c}{$\begin{array}{c}\text { Only Conventional } \\
\text { Mine Openings }\end{array}$} & \multicolumn{2}{c}{$\begin{array}{c}\text { Only Artisanal } \\
\text { Mine Openings }\end{array}$} \\
\cline { 2 - 7 } & $(1)$ & $(2)$ & $(3)$ & $(4)$ & $(5)$ & $(6)$ \\
\hline $1[T] \times 1[2015]$ & -208.4 & & -111.6 & & -98.87 & \\
& $(132.4)$ & & $(139.3)$ & & $(124.1)$ & \\
$1[T] \times 1[2016]$ & & -67.33 & & -51.30 & & 70.37 \\
$\mathrm{~N}$ & & $(62.62)$ & & $(46.25)$ & & $(122.0)$ \\
& 442 & 435 & 367 & 363 & 365 & 360 \\
\hline
\end{tabular}

Notes: Data from SINIM. Using the number of certificates of occupancy as the response variable. All regressions include city and region $\times$ year fixed effects. Standard errors clustered by region in parentheses. Significance levels: ${ }^{*} p<0.10,{ }^{* *} p<0.05,{ }^{* * *} p<0.001$.

Table A10: Robustness Check: Certificates of Occupancy 

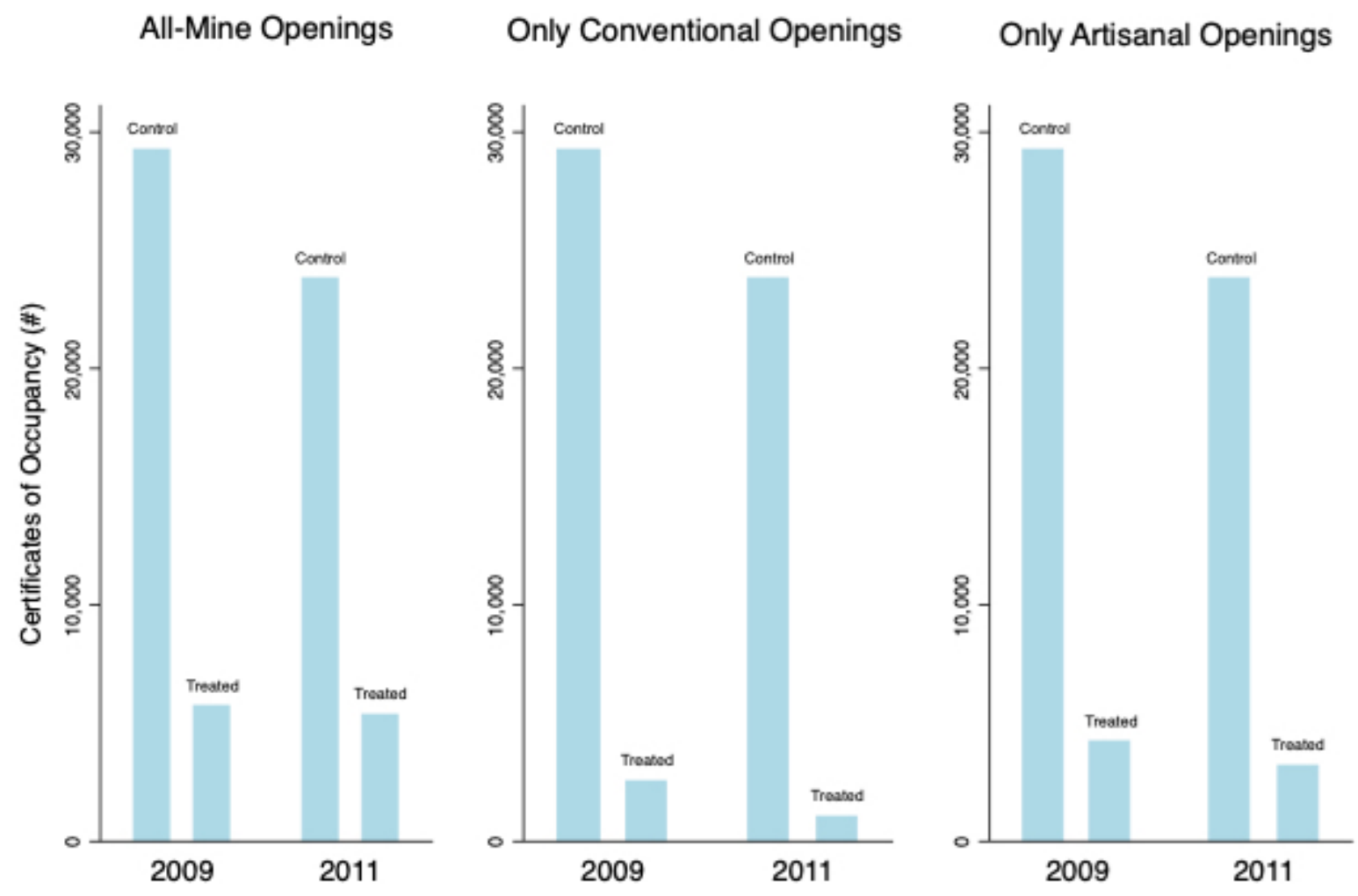

Pre-Treatment Periods

Notes: Excluding two cities with abnormalities in their reports: Huasco (all-mine openings) and Vitacura (control). Source: SINIM (2017).

Figure A6: Overview of the Common Trends Assumption on Certificates of Occupancy. Pre-treatment Periods 